\title{
Palm-based Diacylglycerol fat dry fractionation: effect of crystallisation temperature, cooling rate and agitation speed on physical and chemical properties of fractions
}

Fractionation which separates the olein (liquid) and stearin (solid) fractions of oil is used to modify the physicochemical properties of fats in order to extend its applications. Studies showed that the properties of fractionated end products can be affected by fractionation processing conditions. In the present study, dry fractionation of palm-based diacylglycerol (PDAG) was performed at different: cooling rates $\left(0.05,0.5,1.0,1.5,2.0,2.5\right.$ and $\left.3.0^{\circ} \mathrm{C} / \mathrm{min}\right)$, end-crystallisation temperatures $(30,35,40$, 45 and $50^{\circ} \mathrm{C}$ ) and agitation speeds (30, 50, 70, 90 and $110 \mathrm{rpm}$ ) to determine the effect of these parameters on the properties and yield of the solid and liquid portions. To determine the physicochemical properties of olein and stearin fraction, : Iodine value (IV), fatty acid composition (FAC), acylglycerol composition, slip melting point (SMP), solid fat content (SFC), thermal behaviour tests were carried out. Fractionation of PDAG fat changes the chemical composition of liquid and solid fractions. In terms of FAC, the major fatty acid in olein and stearin fractions were oleic (C18:1) and palmitic (C16:0) respectively. Acylglycerol composition showed that olein and stearin fractions is concentrated with TAG and DAG respectively. Crystallization temperature, cooling rate and agitation speed does not affect the IV, SFC, melting and cooling properties of the stearin fraction. The stearin fraction was only affectted by cooling rate which changes its SMP. On the other hand, olein fraction was affected by crystallization temperature and cooling rate but not agitation speed which caused changes in IV, SMP, SFC, melting and crystallization behavior. Increase in both the crystallization temperature and cooling rate caused a reduction of IV, increment of the SFC, SMP, melting and crystallization behaviour of olein fraction and vice versa. The fractionated stearin part melted above 65 ${ }^{\circ} \mathrm{C}$ while the olein melted at $40^{\circ} \mathrm{C}$. SMP in olein fraction also reduced to a range of 26 to $44^{\circ} \mathrm{C}$ while SMP of stearin fractions increased to $\left(60-62^{\circ} \mathrm{C}\right)$ compared to PDAG. 


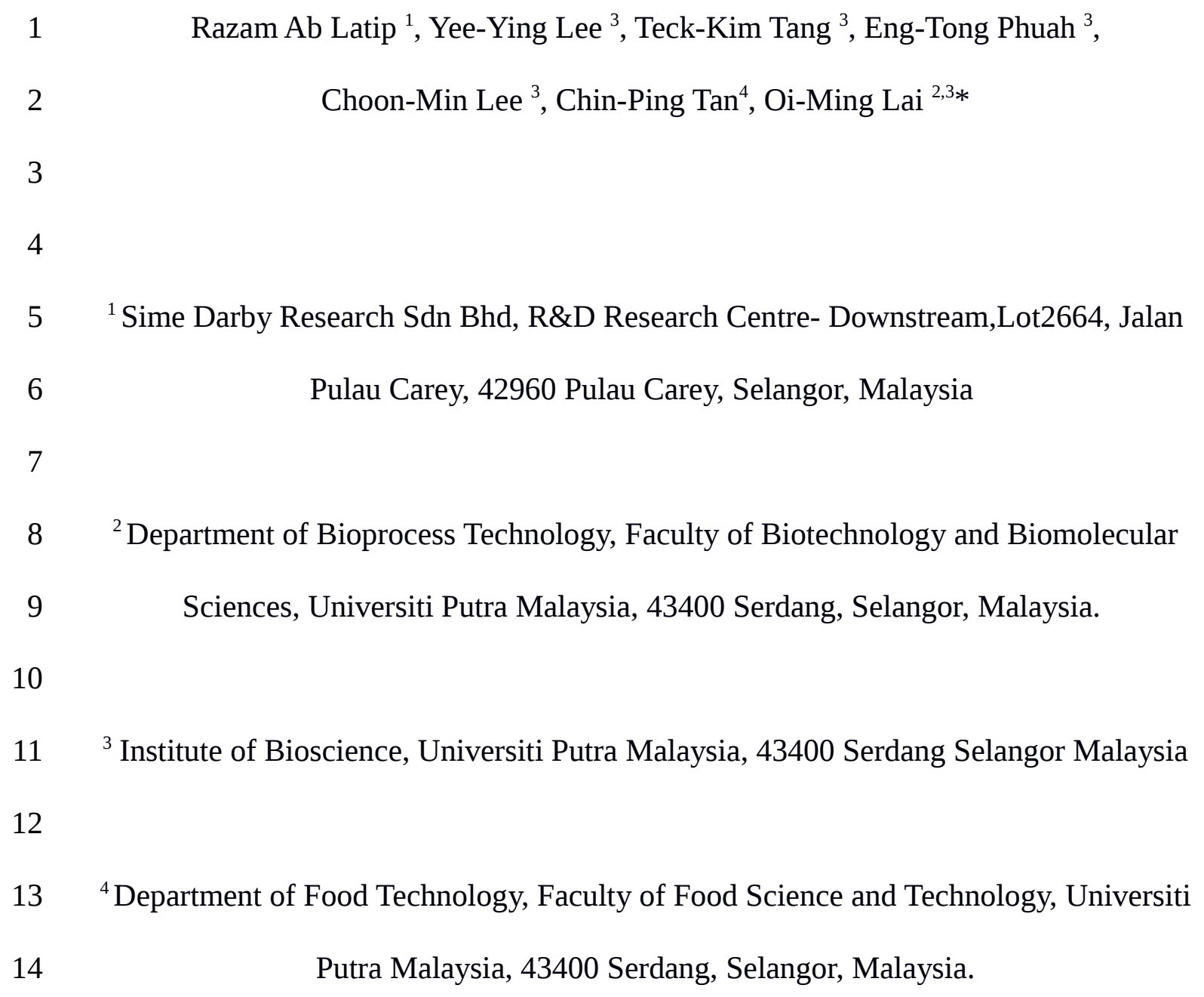




\section{Introduction}

2 Obesity is a metabolic disease resulting from the increase of body fat. Obesity is referred

3 as a global epidemic due to its rapid growth rate. In 2004, WHO estimates that more than

4 one billion people are overweight and, of these, 300 million can be considered as obese.

5 Obesity happened in both the developed and developing countries. A progressive increase

6 in obesity rate is found in countries such as United States, Brazil, England and Japan

7 (James et al. 2001). Prevalence cases of childhood obesity are increasing as well

8 (Deckelbaum \& Williams 2001). It is estimated that if no action is taken against this,

9 these figures could double in 2025. Obesity is often correlated with coronary heart

10 disease, diabetes mellitus, and certain types of cancer. This results in an increased in the

11 global anti-obesity market, which is currently about USD 240 billion.

12

13 Diacylglycerols (DAG) oil has metabolic characteristics that are distinct from 14 triacylglycerols (TAG) oil. The consumption of DAG oil is claimed to be able to reduce

15 postprandial serum TAG levels and thus beneficial for the prevention and management of 16 obesity (Lo et al. 2008). DAG can be produced from various types of vegetable oils

17 including palm oil. However, the slip melting point of palm based DAG fat is high (more

18 than $50{ }^{\circ} \mathrm{C}$ ) hence, limiting its application in food products. Moreover, the high solid fat

19 content of palm-based DAG fat, which is about $17 \%$ at body temperature, results in an 20 undesirable mouth feel. Modification such as fractionation is necessary in order to 21 improve their properties.

22 
1 Fractional crystallization is a reversible modification process, carried out in 2 stages;

2 crystallization and followed by separation (Kellens et al. 2007), done through

3 dry-fractionation. Dry fractionation has gained popularity because of its cheaper process

4 and greener technology. Also, there is no harmful effluent, no chemical used and no loss

5 in yield. Because palm oil contains a mixture of high and low melting glycerides, higher

6 melting glycerides will crystallize into solid (stearin) fraction which can be used for

7 margarine and shortening, while the low melting glycerides remain in a liquid form called

8 olein used for frying media.

9

10 The dry fractionation process is simply a controlled crystallization of the melted oil, 11 followed by separation of solid from liquid fraction. Three steps are involved in 12 crystallization process; super cooling of the melt, nucleation and crystal growth (Zaliha et 13 al. 2004). The separation is an important step since the amount of liquid fat entrapped in

14 the filter cake will affect the physical properties of this fraction, called stearin, to a great 15 extent. The entrapment of the liquid fat is due to occlusion within crystallized particles or 16 aggregates as well as retention between particles (Hamm 1995). The formations of mixed 17 crystals in the form of agglomerated spherulites, which adsorb liquid within crystals, and 18 depend to a considerable, extend to the crystallisation conditions employed (Patience et 19 al. 1999). The amount of liquid oil remaining between crystals in the filter cake is 20 determined by the number, size, shape and chemical composition of the crystals and the 21 mechanism of filtration (Amer et al. 1985). In fats and oil industries, dry fractionation is 22 commonly used to produce a value added stearin and oleic fraction such as palm oil, 23 coconut oil, high-olein high-stearic sunflower oil, milk fat (Bootello et al. 2011; Chaleepa 
1 et al. 2010; Lopez \& Ollivon 2009). Dry fractionation is preferable compared to the

2 solvent fractionation as no chemical is involved in this process and it is more economical.

4 In this study, we performed dry fractionation of palm-based DAG (PDAG) fat at various

5 cooling rates $\left(0.05,0.5,1.0,1.5,2.0,2.5\right.$ and $\left.3.0{ }^{\circ} \mathrm{C} / \mathrm{min}\right)$, end-crystallisation

6 temperatures (30, 35, 40, 45 and $50{ }^{\circ} \mathrm{C}$ ) and agitation speeds (30, 50, 70, 90 and $110 \mathrm{rpm}$ )

7 to see the effects of these parameters on the properties and yield of the solid and liquid

8 portions of the DAG fat. Fractionation of this functional oil PDAG can help to extend the

9 applications of PDAG in food application with its stearin and olein fraction. Dry

10 fractionation is only applicable for PDAG but not for other soft oils.

\section{Materials \& Methods}

\section{Materials}

15 PDAG fat was produced from refined palm oil (RBDPO), provided by Sime Darby 16 Jomalina Food Industries Sdn. Bhd. (Telok Panglima Garang, Selangor, Malaysia), 17 through 1,3-lipase glycerolysis using Novozyme 435 lipase (Novozyme, Denmark) 18 according to Malaysia Patent 201004803. Free fatty acid (FFA) and monoacyglycerides 19 (MAG) were removed using short-path distillation (SPD) to achieve DAG purity of more 20 than $80 \%(w / w)$. All chemicals used were of analytical grade except for GC and HPLC 21 purposes, the solvents used were HPLC grade.

22

\section{Fractional crystallization}


1 The PDAG fat (400 ml) with free fatty acid (FFA) of less than $0.16 \%$ was subjected to

2 dry fractionation using Mettler Toledo LabMax (Greifensee, Switzerland) reactor. The oil

3 was first heated in the reactor for $20 \mathrm{~min}$ at $70{ }^{\circ} \mathrm{C}$ with stirring at $100 \mathrm{rpm}$ to destroy all

4 crystals. The oil was then agitated and cooled at controlled manner to the desired

5 end-temperature. The examined process parameters were summarized in Table 1 . The oil

6 was hold in the crystalliser for stabilization followed by separation of the semi-slurry into

7 olein and stearin using hydraulic filter press. The slurry was first fed into the filter press

8 with a minimum pressure $2.0 \mathrm{bar} / \mathrm{min}$. The filling period was $10 \mathrm{~min}$ with a maximum

9 pressure $6.0 \mathrm{bar} / \mathrm{min}$. The olein and stearin fraction were weighed and analysed.

10

\section{Iodine value (IV) determination}

12 IV was determined according to the AOCS official method Cd 1-25 (1993).

\section{Fatty acid composition (FAC) analysis}

15 Fatty acid composition was determined by the rapid method of AOCS Official Method

16 Cd 14c-94 (1993). Analysis of fatty acid compositions was done by gas chromatography

17 (Model: Autosystem XL, Perkin Elmer, USA). Fatty acids present in oil were first

18 converted to fatty acid methyl esters (FAME) before injecting into polar $\mathrm{SP}^{\mathrm{tm}}$ (Supelco,

19 Bellefonte, PA) capillary column (0.25 mm i.d x $60 \mathrm{~m} \mathrm{x} 0.2 \mu \mathrm{m})$, to obtain the fatty acid

20 profiles. Temperatures maintained in the analysis were column oven: $130{ }^{\circ} \mathrm{C}$, injection

21 block: $250^{\circ} \mathrm{C}$ and detector temperature: $250^{\circ} \mathrm{C}$. Carrier gas was nitrogen at 20 psi. The

22 injection volume was $1 \mu \mathrm{l}$. 


\section{Analysis of acylglycerol composition}

2 PDAG fat, olein and stearin fractions (100 $\mu \mathrm{l})$ were dissolved in solutions of acetone:

3 acetonitrile (60:40) (v/v) (900 $\mu \mathrm{l})$ and then analyzed for triacyglycerol composition using

4 reversed-phased high performance liquid chromatography (Waters 2695, Connecticut,

5 USA) using AOCS method Ce 5C-93. The TG was separated using packed Supercosil ${ }^{\mathrm{TM}}$

6 LC-18 column (25 cm x $4.6 \mathrm{~mm}$ i.d x $5 \mu \mathrm{m}$ ) and eluted from the column using an

7 acetone/acetonitrile (25:75 vol/vol) mobile phase at flow rate of $2 \mathrm{ml} / \mathrm{min}$. The sample

8 injection volume was $1 \mu \mathrm{l}$. Detection of the TG was done using refractive index detector

9 (Waters 2414, Connecticut, USA).

10

\section{Slip melting point (SMP)}

12 SMP was measured according to AOCS Method Cc.3.25 (1993). Capillary tubes were

13 filled with a $1 \mathrm{~cm}$ high column of melted fat. The capillary tubes were then rolled against

14 a piece of ice before being chilled in a refrigerator at $101{ }^{\circ} \mathrm{C}$ for $16 \mathrm{~h}$ to solidify the fat.

15 The tubes were subsequently attached with a rubber band to a thermometer and

16 suspended in a $600 \mathrm{ml}$ beaker of boiled distilled water. The bath temperature was adjusted

17 to $8-10{ }^{\circ} \mathrm{C}$ below the SMP of the sample, and heat was applied using a heating coil

18 element to increase the bath temperature at a rate of $1{ }^{\circ} \mathrm{C} / \mathrm{min}$. The temperature at which

19 the fat column rises was reported as the SMP.

\section{Solid fat content (SFC)}

22 SFC was measured according to Malaysian Palm Oil Board (MPOB) Test Method p4.8

23 (2004) using pulsed nuclear magnetic resonance (NMR) spectrometry (Bruker NMS 120 
1 minispec). The SFC of PDAG fat, olein and stearin fractions was measured at each

2 separation temperature. The sample in the NMR tube was first melted at $70{ }^{\circ} \mathrm{C}$ for 30

3 min, followed by chilling at $0{ }^{\circ} \mathrm{C}$ for 90 min prior to measurement. Melting, chilling and

4 holding of sample were carried out in pre-equilibrated thermostat water bath. The SFC

5 temperature was set to $10,20,25,30,35,40,45,50,55,60,65^{\circ} \mathrm{C}$. The percentage of

6 SFC was based on three measurements.

7

8 Thermal behavior by differential scanning calorimetry (DSC)

9 Thermal properties of the oil sample (3-5 mg) was measured using a Perkin Elmer DSC

10 Diamond with hyperDSC (PerkinElmer Ins., Bridgeport Avenue, Shelton, USA). The data

11 processor was PerkinElmer Diamond DSC Auto-sampler. Nitrogen (99.99\% purity) was

12 use as the purge gas and flowed at $20.0 \mathrm{ml} / \mathrm{min}$. The DSC instrument was calibrated with

13 indium (m.p. $\left.156.6^{\circ} \mathrm{C}\right)$.

14

15 Statistical Analysis

16 Statistical analysis software (Xlstat's, Addinsoft, New York, USA) was used to perform

17 statistical analysis. Analysis of variance (ANOVA) with Duncan's multiple range tests

18 was performed to determine significant of difference at $\mathrm{P}<0.05$. Analysis was conducted

19 in triplicates.

20

21 Results and Discussion

22

23 IV, SFC and Percentage of Yield 
1 IV is a measure of the degree of unsaturation of fats and oils. It is one of the parameters

2 commonly used to measure the quality of olein (Haryati et al. 1998). Fractionation of

3 PDAG fat changes the chemical composition of liquid and solid fractions. As the

4 crystallisation proceeds, the more unsaturated fatty acid gradually concentrate in liquid

5 phase, known as olein, leaving behind the more saturated in solid phase, stearin. The fatty

6 acid composition is altered, as expected. The unsaturated fatty acid, were present in

7 higher concentrations in olein fractions.

9 Table 2 shows the effect of different crystallisation temperature on chemical 10 composition of olein and stearin fractions obtained by dry fractionation of PDAG fat.

11 The present result shows that crystallisation temperature has effect on the IV of olein

12 fraction but not on stearin fraction. A clear correlation $\left(\mathrm{R}^{2}=0.812\right)$ between IV of olein

13 and crystallisation temperature was observed. Olein fractionated at higher crystallisation

14 temperature had lower IV. A reduction in IV of olein fraction was observed as the

15 crystallisation temperature increased from 30 to $50{ }^{\circ} \mathrm{C}$. However, there is no significant

16 difference $(\mathrm{P}>0.05)$ in IV of olein fraction fractionated at crystallisation temperature of

1730,35 and $40^{\circ} \mathrm{C}$. As crystallization temperature decreased, more unsaturated

18 components were concentrated at the liquid fraction which contributed to higher IV

19 (Table 2). A clear correlation $\left(\mathrm{R}^{2}=0.9490\right)$ between crystallisation temperature and the

20 amount oleic acid, C18:1, was also observed (Table 2). A significant decrease $(\mathrm{P}<0.05)$

21 in oleic acid resulted in lower amount of monounsaturated fatty acids (MUFA) and 22 polyunsaturated fatty acids (PUFA). One can also observed that saturated fatty acids 23 (SAFA) gradually increased as crystallisation temperature increased and this might be 
1 the result from the increasing palmatic acid concentration. This demonstrated that olein

2 fractions have become more saturated thus, contributed to lower IV for olein fractions.

3 This conclusion is in line with the results of Arnaud \& Collignan (2008) who studied the

4 effect of the temperature and time on crystallisation, filtration and fraction properties on

5 chicken fat fractionation and showed that the longer crystallisation time and the high

6 suspension viscosity might possibly preserve the crystalline integrity at low

7 temperatures. In a study by Mamat et al. (2005) on palm and sunflower oil blends

8 fractionated using different temperatures, it was reported that higher IV can be obtained

9 due to higher PUFA propotion found in liquid fraction when lower fractionation

10 temperature was applied. However, no correlation $\left(\mathrm{R}^{2}=0.2499\right)$ between IV of stearin

11 and crystallisation temperature was observed in the present study. This is probably

12 related to an inconsistency in separation processes. In our study, separation was done by

13 manual pressing therefore; the pressure and the duration of pressing were not effectively

14 controlled. Hence, an increased in olein entrapment might have contributed to an

15 increase in IV of stearin and vice versa. The IV for PDAG fat (49.86) was intermediate

16 between olein and stearin fractions as PDAG fat has equal proportion of saturated and

17 unsaturated fatty acids (Table 2).

19 Cooling rate influenced the nature of crystals obtained. The effect of different cooling 20 rates on chemical compositions of olein and stearin fractions obtained by dry

21 fractionation of PDAG fat is shown in Table 3. Similar to the effect of crystallisation

22 temperature, the IV of the olein fraction is influenced by the cooling rate but not the

23 stearin fraction. A clear correlation $\left(\mathrm{R}^{2}=0.7373\right)$ between IV of olein and cooling rate 
1 was identified in this study. As cooling rate increased, the iodine value of olein fractions

2 decreased. Table 3 shows SAFA increased while MUFA decreased as cooling rate

3 increased for olein fractions. Significant decrease $(\mathrm{P}<0.05)$ in MUFA composition was

4 influenced by the reduction of oleic acid (C18:1). This contributed to lower IV for olein

5 fractions. However there is no significant difference $(\mathrm{P}>0.05)$ in IV for cooling rates of

$60.05,0.5,1.0$ and $1.5^{\circ} \mathrm{C} / \mathrm{min}$. This finding is similar to what was reported by (deMan

7 1964) and (Schaap and Rutten 1976) who found little difference in slip point, solid fat

8 content (SFC), yield, hardness, thermal melting curves, and fatty acid composition over

9 the ranges from 0.01 to $1^{\circ} \mathrm{C} / \mathrm{min}$ of cooling rate. However, in this study, no correlation

$10\left(\mathrm{R}^{2}=0.010\right)$ between IV and cooling rate was observed for the stearin fractions, probably

11 due to inconsistency in the separation steps as mentioned earlier. The increment in IV for

12 the stearin fraction was simply due to the presence of higher quantity of entrained olein in

13 the stearin fractions which resulted in higher stearin yield as showed in Table 3.

14 Increased IV due to olein entrapment was evidenced by the increased and decreased in

15 oleic acid and palmatic acid, respectively, i.e. higher MUFA and lower SAFA contents

16 were detected. According to deMan (1964), a slower crystallisation process will led to a

17 decreased solid fat content, the hardness of milk fat, as well as the aggregation of small

18 crystalline particles into larger crystalline particles.

20 There are many factors that can influence lipid crystallization. One of the most notable is

21 the process by which the melted sample is cooled down. This includes the cooling rate,

22 crystallisation temperature and also agitation speed. The main function of agitation

23 during fat fractionation was suspending the crystal aggregates and enhancing the heat 
1 transfer. Table 4 shows the effect of different agitation speed on chemical composition of

2 olein and stearin fractions obtained by dry fractionation of PDAG fat. For the

3 experimental conditions described here, IV did not seem to be affected by agitation. No

4 correlation between IV and agitation speed was observed in olein $\left(\mathrm{R}^{2}=0.096\right)$ and stearin

$5 \quad\left(R^{2}=0.139\right)$ fractions. However, stearin fractionated at $50 \mathrm{rpm}$ has highest IV (Table 4)

6 which was possibly because of high olein entrapment resulting in high stearin yield. In

7 contrast with the study conducted by (Vanhoutte et al. 2003) on the filtration properties

8 and crystallisation kinetics of milk fat fractionation. They performed experiments at 13 to

925 rpm to investigate the effect of higher agitation speed and found that more intense

10 agitation produced softer stearin as a result of more oil inclusion. The result was

11 explained by higher shear rates, which break down crystal aggregates. Agitation rate had

12 a marked effect on crystal size. Higher agitation rate had a dramatic effect on crystal size

13 resulting in formation of many small crystals (Herrera \& Hartel 2000), which is perhaps

14 evidence of secondary nucleation caused by crystal contact mechanism (Hartel 2001).

15 (Martini et al. 2002) reported that blends of a high milk fat fraction and sunflower oil

16 crystallised without agitation appeared to be more densely arranged within the crystal and

17 to have bigger crystal sizes than samples crystallized in dynamic conditions. Breitschuh

18 \& Windhab (1996) showed that higher agitation promotes co-crystallization, probably

19 due to an enhanced heat transfer.

21 The stearin yield is strongly dependent on the crystallisation temperatures and agitation

22 speed but not cooling rate (Table 2, 3 \& 4). As crystallisation temperature increased, the 23 yield of stearin fractions decreased (Table 2). This is because less crystal were formed at 
1 higher temperature hence reducing the amount of solid fractions. At the same time,

2 intense agitation resulted in formation of small crystals which reduced the amount of

3 solid fraction. Herrera \& Hartel (2000) found that higher agitation rates led to formation

4 of smaller fat crystals in a milkfat model system. The formation of smaller crystal

5 resulted in poor separation hence reduced the amount of solid fraction. Similar result was

6 also reported by Vanhoutte et al. (2003) on the effect of crystallisation temperatures but

7 not agitation speed.

9 The acylglycerol composition can be altered from the feed oil as expected. The propotion

10 of TAG was higher in the olein, whereas DAG is concentrated in the stearin fraction

11 (Table 2, 3 \& 4). The influence of process parameters on the glyceride composition was

12 insignificant compared to the changes in physical properties hence it was not

13 investigated.

15 SFC

16 Figure 1A shows the SFC of PDAG fat and its fractions at different cooling rate. The

17 olein fractions curves showed lower SFC compared to PDAG fat. It was observed that

18 olein fractionated at lower cooling rates of $0.05,0.5$ and $1.0^{\circ} \mathrm{C} / \mathrm{min}$ were completely

19 melted at lower temperature $\left(40{ }^{\circ} \mathrm{C}\right)$ whereas, the SFC for olein fractionated at 1.5 and

$202.0^{\circ} \mathrm{C} / \mathrm{min}$ still retained at $0.97 \%$ and $3.1 \%$, respectively. At cooling rate of $2.0^{\circ} \mathrm{C} / \mathrm{min}$,

21 the SFC of olein fraction was highest due to high content of SAFA and low amount of

22 unsaturated fatty acids. As crystallisation temperature decreased, the SFC for the olein

23 fractions decreased. Ol 30 and $\mathrm{Ol} 35$ completely melted at body temperatures whereas, 
1 the solid fat of $\mathrm{Ol} 40$, Ol 45 and $\mathrm{Ol} 50$ still retain at 2.42, 2.82 and $8.32 \%$, respectively

2 (Figure 1B). Agitation speed does not affect the SFC of the olein fractions (Figure 1C).

3 The SFC of stearin fractions (Figure 1A-1C) are all higher than the SFC of palm-based

4 DAG fat and were melted at temperatures above $65{ }^{\circ} \mathrm{C}$. This is due to the fact that the

5 stearin fractions contained higher amounts of saturated fat with high melting points and

6 were crystallized out at higher temperatures during the fractionation process. One can

7 observed that the SFC of stearin fractions is not influenced by these three parameters.

8

9 SMP

10

11 The SMP of PDAG, olein and stearin fractionated at various cooling rates, crystallisation

12 temperature and agitation speeds are shown in Table 5. PDAG fat has a SMP of $51.6^{\circ} \mathrm{C}$.

13 Upon fractionation, the SMP for the olein fractions were reduced to a range of 26 to 44

$14{ }^{\circ} \mathrm{C}$. In contrast, the SMP of stearin fractions increased $\left(60-62{ }^{\circ} \mathrm{C}\right)$. This is due to an

15 increase in the amount of saturated fatty acid (C16:0) and decreased in unsaturated fatty

16 acids (C18:1) in the stearin fractions, as indicated in Table 2 to Table 4. SMP of the olein

17 but not stearin fraction is influenced by the cooling rate. No significant difference

18 ( $>0.05)$ in the SMP of the olein fractions was observed as the cooling rate increased

19 from 0.05 to $1.00{ }^{\circ} \mathrm{C} / \mathrm{min}$. However, fractionation of PDAG fat at higher cooling rate

20 showed significant increase $(\mathrm{P}<0.05)$ in the SMP of the olein fractions. Large increase in

21 SMP was observed when cooling rate increased from 1.50 to $2.00 \mathrm{C} / \mathrm{min}$. Based on our

22 DSC study (Figure $2 \mathrm{Ab}(\mathbf{i})$ ), olein fractionated at $2.00 \mathrm{C} / \mathrm{min}$ contained high proportion

23 of high melting components resulting in high SMP. However, no significant difference 
1 ( $>0.05)$ was observed in the SMP of stearin fractions. Fractionation at higher

2 crystallization temperature showed significant increased $(\mathrm{P}<0.05)$ in SMP of olein

3 fractions (Table 5).

4

5 SMP of the olein fraction is affected by the crystallization temperature, but not for the

6 stearin fraction. The SMP of olein increased from 28.6 to $44{ }^{\circ} \mathrm{C}$ as crystallisation

7 temperatures increased from 30 to $50{ }^{\circ} \mathrm{C}$. The melting thermogram (Figure 2B b(i))

8 showed an increase in high melting components as crystallisation temperature increased.

9 Increasing the crystallization temperature leads to the broadening of the crystallization

10 exotherm which refers to a longer crystallisation process (Figure 2B a(i)). This shows

11 that olein fractions have become more saturated thus, contributed to higher SMP for olein

12 fractions. Insignificant differences in the SMP of stearin fractions indicated that

13 crystallisation temperature does not influence the SMP of the stearin. An increase in

14 agitation speed showed no significant difference in the SMP of both olein and stearin

15 fractions indicating that fractionation of PDAG fat is not influenced by agitation speed.

\section{Thermal behavior properties}

18 Figure 2A to 2C shows the crystallisation and melting curves of PDAG fat and its

19 fractions at different cooling rate, crystallisation temperature and agitation speeds. The

20 crystallisation and melting curves recorded by DSC showed different crystallisation and

21 melting peaks for PDAG and its fractions. Two major endothermic peaks; 53.78 and

$2223.41{ }^{\circ} \mathrm{C}$ and one minor peak; $-4.34{ }^{\circ} \mathrm{C}$ were observed in PDAG fat melting thermogram

23 (Figure 2A b(i)). PDAG stearin though showed two melting peaks and like its parent 
1 fats, the proportion of these peaks are different and also the first peak (Pk1) is shifted

2 towards a higher temperature (Figure $2 \mathrm{~A} \mathbf{b}$ (ii), $2 \mathrm{~B}$ b(ii) and 2C b(ii)).

4 The proportion of low melting peak is reduced and that of the higher peaks are increased

5 in stearin compared to its original fat due to the removal of the liquid fraction, which is

6 reflected in SFC (Figure 1A to 1C) and melting profiles (Figure 2A to 2C). The SFC at

7 all temperatures is increased in stearin compared to the original fat and thus the plasticity

8 is improved (Figure 2A to 2C). PDAG stearin showed one exothermic peak which

9 attributed to the high melting component being shifted to a higher temperature compared

10 to its original fat and this is expected due to the removal of liquid fraction (Figure 2A

11 a(ii), 2B a(ii) and 2C a(ii)). The stearin fractions did not show differences in melting and

12 crystallization behaviors with changes in processing parameters. One can conclude that

13 the melting properties of stearin fractions were not influenced by the cooling rate,

14 crystallisation temperatures and agitation speeds.

15

16 The olein fractionated at different cooling rates showed 4 exothermic peaks similar to

17 PDAG fat, indicating that the high melting components were not completely removed

18 (Figure 2A a(i)). However, olein showed very small high melting peak unlike parent fat

19 or stearin part. The olein though showed 3 melting peaks like PDAG fat, but the

20 proportion of these peaks are different (Figure 2A b(i)). The proportion of high melting

21 peak is reduced. One can conclude that fractionation of PDAG fat at cooling rates from

220.05 to $2.00{ }^{\circ} \mathrm{C} /$ min produced harder olein. This is supported by the SFC profile which

23 showed complete melting at temperature above $35^{\circ} \mathrm{C}$ (Figure 1A). 
2 Fractionation at higher crystallisation temperature produced olein with high proportion of

3 high melting components. Cooling and melting thermograms (Figure 2B a(i) and 2B

4 b(i)) of olein fractionated at $50{ }^{\circ} \mathrm{C}$ displayed one peak at higher temperature region at

532.68 and $45.99^{\circ} \mathrm{C}$, respectively and this was attributed to the high melting components,

6 which contributed to higher SFC (Figure 1B). However, olein obtained from removal of

7 stearin at lower temperatures showed two melting peaks and three exothermic peaks at

8 lower temperature regions due to the removal of higher melting fractions. The olein

9 fractionated at different agitation speed showed three crystallisation peaks (Figure 2C

10 a(i)) and two endothermic peaks (Figure 2C b(i)). One can observe that agitation speed

11 does not influence the melting and cooling properties of the olein fractions.

13 Conclusion

14 Dry fractionation process is environmental friendly and a well established method used in

15 the fats and oils industry to separate the olein (liquid fraction) and stearin fraction (solid

16 fraction) of fats and oils so as to extend their applications especially in the food industry.

17 It is important to know that different types of fats and oils require different types of 18 operating parameters during fractionation. The influence of these parameters such as 19 crystallization temperature, cooling rate and agitation speed during the fractionation 20 process need to be taken into consideration in order to obtain a good quality olein and 21 stearin fraction. In the present study, the effect of crystallisation temperature, cooling rate 22 and agitation speed on physical (DSC, SMP, thermal behaviour) and chemical properties 23 (IV) of the stearin and olein of palm-based diacylglycerol was studied. Crystallisation 
1 temperature and cooling has an influence on the chemical property of the olein fraction

2 but not for the stearin fraction. On the other hand, agitation speed does not has any affect

3 on both the chemical properties of olein and stearin fraction. 


\section{References}

AOCS.1993. Official and tentative methods of the American Oil Chemists' Society. Champaign. Illinois: AOCS Press.

Amer MA, Kupranycz DB, and Baker BE. 1985. Physical and chemical characteristics of butterfat fractions obtained by crystallization from molten fat. Journal of the American Oil Chemists’ Society 62:1551-1557.

Arnaud E, and Collignan A. 2008. Chicken fat dry fractionation: Effects of temperature and time on crystallization, filtration and fraction properties. European Journal of Lipid Science and Technology 110:239-244.

Bootello M, Garcés R, Martínez-Force E, and Salas J. 2011. Dry Fractionation and Crystallization Kinetics of High-Oleic High-Stearic Sunflower Oil. Journal of the American Oil Chemists' Society 88:1511-1519.

Breitschuh B, and Windhab E. 1996. Direct measurement of thermal fat crystal properties for milk-fat fractionation. Journal of the American Oil Chemists' Society 73:1603-1610.

Chaleepa K, Szepes A, and Ulrich J. 2010. Dry fractionation of coconut oil by melt crystallization. Chemical Engineering Research and Design 88:1217-1222.

Deckelbaum RJ, and Williams CL. 2001. Childhood Obesity: The Health Issue. Obesity Research 9:239S-243S.

Hamm W. 1995. Trends in edible oil fractionation. Trends in Food Science \& Technology 6:121-126.

Haryati T, Che Man YB, Ghazali HM, Asbi BA, and Buana L. 1998. Determination of iodine value of palm oil based on triglyceride composition. Journal of the American Oil Chemists' Society 75:789-792.

Herrera ML, and Hartel RW. 2000. Effect of processing conditions on physical properties of a milk fat model system: Rheology. Journal of the American Oil Chemists' Society 77:1189-1196.

James PT, Leach R, Kalamara E, and Shayeghi M. 2001. The Worldwide Obesity Epidemic. Obesity Research 9:228S-233S.

Kellens M, Gibon V, Hendrix M, and De Greyt W. 2007. Palm oil fractionation. European Journal of Lipid Science and Technology 109:336-349.

Lo S-K, Tan C-P, Long K, Yusoff MS, and Lai O-M. 2008. Diacylglycerol OilProperties, Processes and Products: A Review. Food and Bioprocess Technology 1:223-233. 
1 Lopez C, and Ollivon M. 2009. Triglycerides obtained by dry fractionation of milk fat: 2. 2 Thermal properties and polymorphic evolutions on heating. Chemistry and $3 \quad$ Physics of Lipids 159:1-12.

4 Mamat H, Nor Aini I, Said M, and Jamaludin R. 2005. Physicochemical characteristics of palm oil and sunflower oil blends fractionated at different temperatures. Food Chemistry 91:731-736.

7 Martini S, Herrera ML, and Hartel RW. 2002. Effect of processing conditions on 8 microstructure of milk fat fraction/sunflower oil blends. Journal of the American Oil Chemists' Society 79:1063-1068.

Patience DB, Hartel RW, and Illingworth D. 1999. Crystallization and pressure filtration of anhydrous milk fat: Mixing effects. Journal of the American Oil Chemists' Society 76:585-594.

13 Vanhoutte B, Dewettinck K, Vanlerberghe B, and Huyghebaert A. 2003. Monitoring milk fat fractionation: Filtration properties and crystallization kinetics. Journal of the American Oil Chemists' Society 80:213-218.

Zaliha O, Chong CL, Cheow CS, Norizzah AR, and Kellens MJ. 2004. Crystallization properties of palm oil by dry fractionation. Food Chemistry 86:245-250. 


\section{Table $\mathbf{1}_{\text {(on next page) }}$}

Experimental conditions.

$\mathrm{Ct}=$ crystallisation temperature; $\mathrm{Cr}=$ cooling rate; $\mathrm{As}=$ agitation speed. $[\mathrm{b}]$ 


\begin{tabular}{|c|c|c|c|c|}
\hline Parameter & $\begin{array}{l}\frac{\bar{c}}{\mathrm{C}} \\
\mathrm{c}\end{array}$ & $\mathbf{C t}$ & $\mathrm{Cr}$ & As \\
\hline $\mathrm{Ct}\left({ }^{\circ} \mathrm{C}\right)$ & $\frac{\vec{c}}{\sigma}$ & $30,35,40,45,50$ & 35 (constant) & 35 (constant) \\
\hline $\mathrm{Cr}\left({ }^{\circ} \mathrm{C} / \mathrm{min}\right)$ & $\sum$ & 0.05 (constant) & $0.05,0.5,1.0,1.5,2.0$ & 0.05 (constant) \\
\hline As (rpm) & $\cdot \frac{5}{3}$ & 90 (constant) & 90 (constant) & $30,50,70,90,110$ \\
\hline
\end{tabular}




\section{Table $2_{\text {(on next page) }}$}

Effect of different crystallisation temperature on chemical composition of olein and stearin fractions obtained by dry fractionation of PDAG fat.

Each value in the table represents the mean \pm standard deviation of sample analysis from triplicate analysis. Means within each column with different superscripts are significantly $(\mathrm{P}<0.05)$ different. $\mathrm{Ol}=$ olein, $\mathrm{St}=$ stearin, Crystallization temperature $=30,35,40,45,50^{\circ} \mathrm{C}$. 


\begin{tabular}{|c|c|c|c|c|c|c|c|c|c|c|c|}
\hline \multirow[t]{2}{*}{ Layer } & \multirow[t]{2}{*}{$\mathrm{Ct}$} & \multicolumn{3}{|c|}{ Acylglycerol Composition (\%) } & \multicolumn{5}{|c|}{ Fatty Acid Composition (\%) } & \multirow[t]{2}{*}{ IV } & \multirow[t]{2}{*}{ Yie } \\
\hline & & $M A G=\frac{\varrho}{2}$ & DAG & TAG & C16:0 & C18:1 & SAFA & MUFA & PUFA & & \\
\hline \multirow[t]{6}{*}{ Ol } & & $\begin{array}{l}0 \\
-\quad \stackrel{\infty}{\beth} \\
\end{array}$ & $97.89 \pm 0.06$ & $2.64 \pm 0.07$ & $44.08 \pm 0.12$ & $39.86 \pm 0.15$ & $49.92 \pm 0.15$ & $40.01 \pm 0.10$ & $10.06 \pm 0.15$ & $49.86 \pm 0.25$ & \\
\hline & 30 & - & $96.23 \pm 0.06^{c}$ & $3.78 \pm 0.07^{\mathrm{b}}$ & $33.53 \pm 0.11^{\mathrm{e}}$ & $49.11 \pm 0.26^{\mathrm{a}}$ & $38.27 \pm 0.18^{\mathrm{e}}$ & $49.30 \pm 0.18^{\mathrm{a}}$ & $12.22 \pm 0.26^{\mathrm{a}}$ & $59.97 \pm 0.31^{\mathrm{a}}$ & וסנ \\
\hline & 35 & - & $96.13 \pm 0.08^{c}$ & $3.88 \pm 0.07^{\mathrm{b}}$ & $34.31 \pm 0.19^{d}$ & $48.35 \pm 0.10^{\mathrm{b}}$ & $39.22 \pm 0.17^{\mathrm{d}}$ & $48.53 \pm 0.20^{\mathrm{b}}$ & $12.03 \pm 0.15^{\mathrm{a}}$ & $59.74 \pm 0.24^{\mathrm{a}}$ & 52. \\
\hline & 40 & - & $96.42 \pm 0.10^{\mathrm{b}}$ & $3.57 \pm 0.08^{c}$ & $34.89 \pm 0.18^{c}$ & $47.81 \pm 0.15^{\mathrm{c}}$ & $39.88 \pm 0.10^{c}$ & $48.00 \pm 0.26^{\mathrm{c}}$ & $11.90 \pm 0.30^{\mathrm{a}}$ & $59.73 \pm 0.28^{\mathrm{a}}$ & \\
\hline & 45 & - & $90.72 \pm 0.10^{\mathrm{d}}$ & $9.30 \pm 0.07^{\mathrm{a}}$ & $36.73 \pm 0.12^{b}$ & $46.22 \pm 0.11^{\mathrm{d}}$ & $41.93 \pm 0.28^{b}$ & $46.40 \pm 0.20^{\mathrm{d}}$ & $11.46 \pm 0.26^{\mathrm{b}}$ & $57.64 \pm 0.36^{\mathrm{b}}$ & 55. \\
\hline & 50 & - & $96.72 \pm 0.05^{\mathrm{a}}$ & $3.27 \pm 0.07^{d}$ & $38.65 \pm 0.20^{\mathrm{a}}$ & $44.55 \pm 0.10^{\mathrm{e}}$ & $43.99 \pm 0.17^{\mathrm{a}}$ & $44.72 \pm 0.10^{\mathrm{e}}$ & $11.07 \pm 0.16^{\mathrm{b}}$ & $55.41 \pm 0.39^{c}$ & 59. \\
\hline \multirow[t]{5}{*}{ St } & 30 & _. & $99.28 \pm 0.06^{\mathrm{d}}$ & $0.71 \pm 0.04^{\mathrm{a}}$ & $67.61 \pm 0.19^{d}$ & $16.18 \pm 0.19^{\mathrm{a}}$ & $75.91 \pm 0.21^{\mathrm{d}}$ & $19.42 \pm 0.17^{\mathrm{a}}$ & $4.58 \pm 0.08^{\mathrm{a}}$ & $24.19 \pm 0.31^{b}$ & 62. \\
\hline & 35 & - & $99.80 \pm 0.06^{a}$ & $0.19 \pm 0.06^{d}$ & $67.47 \pm 0.20^{\mathrm{d}}$ & $19.58 \pm 0.17^{a}$ & $75.62 \pm 0.27^{\mathrm{d}}$ & $19.64 \pm 0.20^{\mathrm{a}}$ & $4.64 \pm 0.05^{\mathrm{a}}$ & $24.91 \pm 0.41^{\mathrm{a}}$ & 47. \\
\hline & 40 & - & $99.35 \pm 0.08^{\mathrm{cd}}$ & $0.63 \pm 0.09^{\mathrm{ab}}$ & $70.14 \pm 0.24^{\mathrm{a}}$ & $17.28 \pm 0.26^{\mathrm{d}}$ & $78.51 \pm 0.28^{a}$ & $17.34 \pm 0.26^{\mathrm{d}}$ & $4.07 \pm 0.08^{c}$ & $21.54 \pm 0.36^{\mathrm{d}}$ & \\
\hline & 45 & - & $99.56 \pm 0.06^{\mathrm{b}}$ & $0.44 \pm 0.05^{c}$ & $69.33 \pm 0.10^{\mathrm{b}}$ & $17.99 \pm 0.21^{\mathrm{c}}$ & $77.61 \pm 0.18^{\mathrm{b}}$ & $18.05 \pm 0.10^{c}$ & $4.26 \pm 0.14^{b}$ & $22.69 \pm 0.21^{\mathrm{c}}$ & 44. \\
\hline & 50 & - & $99.41 \pm 0.05^{c}$ & $0.60 \pm 0.06^{\mathrm{b}}$ & $68.41 \pm 0.19^{c}$ & $18.76 \pm 0.11^{b}$ & $76.55 \pm 0.17 \mathrm{c}$ & $18.83 \pm 0.18^{\mathrm{b}}$ & $4.52 \pm 0.08^{\mathrm{a}}$ & $23.23 \pm 0.23^{c}$ & \\
\hline
\end{tabular}

$\mathrm{Ct}=$ crystallization temperature, $\mathrm{Ol}=$ Olein, $\mathrm{St}=$ Stearin, $\mathrm{SAFA}=$ Saturated fatty acid, MUFA= monounsaturated fatty acid, $\mathrm{PUFA}=$ polyunsaturated fatty acid. Each value in table represent the mean \pm standard deviation of sample analysis from triplicate analysis. Mean within each column with different superscripts are significantly $(\mathrm{P}<0.05)$ different. 


\section{Table 3 (on next page)}

Effect of different cooling rates on chemical composition of olein and stearin fractions obtained by dry fractionation of palm-based diacylglycerol fat.

Each value in the table represents the mean \pm standard deviation of sample analysis from triplicate analysis. Means within each column with different superscripts are significantly $(\mathrm{P}<0.05)$ different. $\mathrm{Ol}=$ olein, $\mathrm{St}=$ stearin, cooling rate $=0.05,0.5,1.0,2.0^{\circ} \mathrm{C} / \mathrm{min}$. 


\begin{tabular}{|c|c|c|c|c|c|c|c|c|c|c|c|}
\hline \multirow[t]{2}{*}{ Layer } & \multirow[t]{2}{*}{$\mathrm{Cr}$} & \multicolumn{3}{|c|}{ Acylglycerol Gamposition (\%) } & \multicolumn{5}{|c|}{ Fatty Acid Composition (\%) } & \multirow[t]{2}{*}{ IV } & \multirow[t]{2}{*}{ Yield (\%) } \\
\hline & & MAG & DASG & TAG & C16:0 & C18:1 & SAFA & MUFA & PUFA & & \\
\hline \multirow[t]{6}{*}{ Ol } & & $0.25 \pm 0.05$ & 86.53馬.10 & $13.23 \pm 0.06$ & $43.52 \pm 0.02$ & $39.62 \pm 0.07$ & $50.49 \pm 0.12$ & $39.86 \pm 0.14$ & $9.64 \pm 0.22$ & $49.51 \pm 0.21$ & - \\
\hline & $\begin{array}{c}0.0 \\
5\end{array}$ & $0.30 \pm 0.05^{\mathrm{b}}$ & $78.04+0.07^{\mathrm{b}}$ & $21.66 \pm 0.09^{c}$ & $34.98 \pm 0.28^{c}$ & $47.10 \pm 0.18^{b}$ & $41.27 \pm 0.16^{\mathrm{d}}$ & $47.29 \pm 0.23^{b}$ & $11.44 \pm 0.18^{\mathrm{a}}$ & $58.83 \pm 0.21^{\mathrm{a}}$ & $75.56 \pm 0.04^{b}$ \\
\hline & 0.5 & $0.40 \pm 0.05^{\mathrm{a}}$ & $78.06+10^{\mathrm{b}}$ & $21.54 \pm 0.08^{c}$ & $34.44 \pm 0.27^{\mathrm{d}}$ & $47.53 \pm 0.24^{\mathrm{a}}$ & $40.68 \pm 0.12^{c}$ & $47.73 \pm 0.14^{\mathrm{a}}$ & $11.61 \pm 0.22^{\mathrm{a}}$ & $58.44 \pm 0.22^{\mathrm{a}}$ & $71.68 \pm 0.02^{\mathrm{d}}$ \\
\hline & $\begin{array}{c}1.0 \\
0\end{array}$ & $0.25 \pm 0.04^{\mathrm{b}}$ & $68.00+\frac{1-10}{\simeq} .13^{d}$ & $31.75 \pm 0.07^{\mathrm{a}}$ & $35.27 \pm 0.12^{\mathrm{bc}}$ & $46.91 \pm 0.10^{\mathrm{bc}}$ & $41.39 \pm 0.15^{c}$ & $47.10 \pm 0.13^{\mathrm{b}}$ & $11.51 \pm 0.22^{\mathrm{a}}$ & $58.45 \pm 0.35^{\mathrm{a}}$ & $76.69 \pm 0.03^{a}$ \\
\hline & $\begin{array}{c}1.5 \\
0\end{array}$ & $0.40 \pm 0.06^{\mathrm{a}}$ & $77.66 \pm 0.07^{c}$ & $21.94 \pm 0.06^{\mathrm{b}}$ & $35.60 \pm 0.17^{\mathrm{b}}$ & $46.59 \pm 0.21^{\mathrm{c}}$ & $41.89 \pm 0.27^{\mathrm{b}}$ & $46.78 \pm 0.15^{c}$ & $11.32 \pm 0.23^{\mathrm{ab}}$ & $58.38 \pm 0.20^{\mathrm{a}}$ & $73.49 \pm 0.06^{\mathrm{c}}$ \\
\hline & 2.0 & $0.25 \pm 0.04^{b}$ & $80.34=10^{\mathrm{a}}$ & $21.94 \pm 0.06^{\mathrm{a}}$ & $37.19 \pm 0.21^{\mathrm{a}}$ & $45.28 \pm 0.16^{\mathrm{d}}$ & $43.52 \pm 0.28^{a}$ & $45.46 \pm 0.17^{\mathrm{d}}$ & $11.01 \pm 0.21^{\mathrm{b}}$ & $57.32 \pm 0.18^{\mathrm{b}}$ & $68.85 \pm 0.03^{\mathrm{e}}$ \\
\hline \multirow[t]{5}{*}{ St } & $\begin{array}{c}0.0 \\
5\end{array}$ & $0.42 \pm 0.04^{b}$ & $97.40_{-0.05^{\mathrm{a}}}$ & $2.60 \pm 0.03^{\mathrm{e}}$ & $71.04 \pm 0.19^{c}$ & $16.18 \pm 0.19^{d}$ & $80.00 \pm 0.23^{\mathrm{a}}$ & $16.26 \pm 0.11^{\mathrm{d}}$ & $3.75 \pm 0.20^{c}$ & $21.80 \pm 0.20^{\mathrm{e}}$ & $24.44 \pm 0.06^{\mathrm{d}}$ \\
\hline & 0.5 & $0.65 \pm 0.07^{\mathrm{a}}$ & $95.66 \pm 0.05^{\mathrm{c}}$ & $3.69 \pm 0.05^{c}$ & $65.28 \pm 0.19^{c}$ & $16.18 \pm 0.19^{d}$ & $80.00 \pm 0.23^{\mathrm{a}}$ & $16.26 \pm 0.11^{\mathrm{d}}$ & $3.75 \pm 0.20^{c}$ & $27.63 \pm 0.27^{\mathrm{b}}$ & $28.32 \pm 0.08^{\mathrm{b}}$ \\
\hline & $\begin{array}{c}1.0 \\
0\end{array}$ & $0.60 \pm 0.06^{\mathrm{a}}$ & $96.09 \pm 0.14^{\mathrm{b}}$ & $3.31 \pm 0.08^{\mathrm{d}}$ & $66.99 \pm 0.14^{\mathrm{bc}}$ & $19.61 \pm 0.24^{c}$ & $75.80 \pm 0.11^{b}$ & $19.71 \pm 0.16^{\mathrm{c}}$ & $4.50 \pm 0.26^{\mathrm{b}}$ & $24.77 \pm 0.15^{\mathrm{d}}$ & $23.31 \pm 0.09^{\mathrm{e}}$ \\
\hline & 1.5 & $0.65 \pm 0.07^{\mathrm{a}}$ & $94.52 \pm 0.08^{d}$ & $4.83 \pm 0.05^{\mathrm{b}}$ & $65.34 \pm 0.16^{\mathrm{b}}$ & $20.94 \pm 0.28^{b}$ & $74.12 \pm 0.16^{\mathrm{c}}$ & $21.00 \pm 0.23^{\mathrm{b}}$ & $4.88 \pm 0.10^{\mathrm{a}}$ & $27.00 \pm 0.30^{c}$ & $26.51 \pm 0.09^{c}$ \\
\hline & 2.0 & $0.65 \pm 0.07^{\mathrm{a}}$ & $94.52 \pm 0.08^{\mathrm{e}}$ & $4.83 \pm 0.05^{\mathrm{a}}$ & $63.63 \pm 0.28^{\mathrm{a}}$ & $22.41 \pm 0.22^{\mathrm{a}}$ & $72.23 \pm 0.10^{\mathrm{d}}$ & $22.52 \pm 0.13^{a}$ & $5.24 \pm 0.16^{\mathrm{a}}$ & $28.05 \pm 0.20^{a}$ & $31.17 \pm 0.03^{a}$ \\
\hline
\end{tabular}

$\mathrm{Cr}=$ cooling rate, $\mathrm{Ol}=$ Olein, $\mathrm{St}=$ Stearin, $\mathrm{SAFA}=$ Saturated fatty acid, MUFA= monounsaturated fatty acid, PUFA= polyunsaturated fatty acid. Each value in table represent the mean \pm standard deviation of sample analysis from triplicate analysis. Mean within each column with different superscripts are significantly $(\mathrm{P}<0.05)$ different. 


\section{Table 4(on next page)}

Effect of different agitation speed on chemical composition of olein and stearin fractions obtained by dry fractionation of palm-based diacylglycerol fat.

Each value in the table represents the mean \pm standard deviation of sample analysis from triplicate analysis. Means within each column with different superscripts are significantly $(\mathrm{P}<0.05)$ different. $\mathrm{Ol}=$ olein, $\mathrm{St}=$ stearin, agitation speed $=30,50,70,90,110 \mathrm{rpm}$. 


\begin{tabular}{|c|c|c|c|c|c|c|c|c|c|c|c|}
\hline \multirow{2}{*}{$\begin{array}{l}\text { Laye } \\
\text { r }\end{array}$} & \multirow[t]{2}{*}{ As } & \multicolumn{3}{|c|}{ 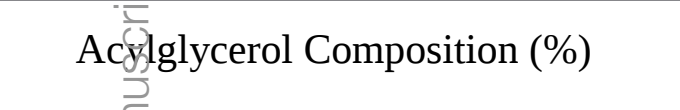 } & \multicolumn{5}{|c|}{ Fatty Acid Composition (\%) } & \multirow[t]{2}{*}{ IV } & \\
\hline & & MAG & DAG & TAG & C16:0 & C18:1 & SAFA & MUFA & PUFA & & \\
\hline \multirow[t]{6}{*}{ Ol } & & $0.25 \pm 0.05$ & $92.53 \pm 0.10$ & $7.22 \pm 0.06$ & $43.52 \pm 0.02$ & $39.62 \pm 0.07$ & 49.49士0.12 & $40.86 \pm 0.14$ & $10.64 \pm 0.22$ & $51.51 \pm 0.21$ & \\
\hline & 30 & $0.36 \pm 0.04^{\mathrm{a}}$ & $93.03 \pm 0.06^{\mathrm{a}}$ & $6.61 \pm 0.07^{\mathrm{d}}$ & $33.34 \pm 0.18^{c}$ & $49.28 \pm 0.15^{\mathrm{a}}$ & $38.07 \pm 0.18^{c}$ & $49.48 \pm 0.11^{\mathrm{a}}$ & $12.45 \pm 0.25^{\mathrm{a}}$ & $61.62 \pm 0.28^{b}$ & \\
\hline & 50 & $0.38 \pm \underset{\Upsilon 0.00}{\simeq} 04^{\mathrm{a}}$ & $92.39 \pm 0.04^{\mathrm{d}}$ & $7.23 \pm 0.05^{c}$ & $33.85 \pm 0.18^{b}$ & $48.80 \pm 0.20^{\mathrm{b}}$ & $38.64 \pm 0.28^{b}$ & $49.00 \pm 0.30^{\mathrm{b}}$ & $12.38 \pm 0.12^{\mathrm{a}}$ & $61.18 \pm 0.30^{\text {bс }}$ & \\
\hline & 70 & $0.38 \pm 0.94^{a}$ & $90.91 \pm 0.06^{\mathrm{e}}$ & $8.71 \pm 0.04^{\mathrm{a}}$ & $34.31 \pm 0.17^{\mathrm{a}}$ & $48.43 \pm 0.20^{\mathrm{b}}$ & $39.15 \pm 0.15^{\mathrm{a}}$ & $48.63 \pm 0.22^{b}$ & $12.25 \pm 0.35^{\mathrm{a}}$ & $60.88 \pm 0.38^{c}$ & \\
\hline & 90 & $0.36 \pm\left(4.02^{a}\right.$ & $92.51 \pm 0.04^{\mathrm{b}}$ & $7.13 \pm 0.11^{\mathrm{c}}$ & $34.02 \pm 0.17^{\mathrm{ab}}$ & $48.65 \pm 0.20^{\mathrm{b}}$ & $38.80 \pm 0.20^{\mathrm{ab}}$ & $48.85 \pm 0.25^{b}$ & $12.36 \pm 0.14^{\mathrm{a}}$ & $61.08 \pm 0.22^{\mathrm{bc}}$ & \\
\hline & 110 & $0.33+04^{a}$ & $91.96 \pm 0.09^{d}$ & $7.71 \pm 0.05^{\mathrm{b}}$ & $33.06 \pm 0.16^{c}$ & $49.47 \pm 0.25^{\mathrm{a}}$ & $37.77 \pm 0.20^{c}$ & $49.67 \pm 0.27^{\mathrm{a}}$ & $12.56 \pm 0.26^{\mathrm{a}}$ & $62.18 \pm 0.27^{\mathrm{a}}$ & \\
\hline \multirow[t]{5}{*}{ St } & 30 & $0.25 \pm 0.04^{\mathrm{ab}}$ & $95.36 \pm 0.06^{c}$ & $4.39 \pm 0.07^{\mathrm{a}}$ & $68.32 \pm 0.16^{\mathrm{a}}$ & $18.71 \pm 0.19^{d}$ & $76.75 \pm 0.18^{\mathrm{a}}$ & $18.78 \pm 0.23^{\mathrm{d}}$ & $4.48 \pm 0.25^{b}$ & $23.65 \pm 0.25^{d}$ & \\
\hline & 50 & $0.27 \pm 0.03^{\mathrm{ab}}$ & $95.91 \pm 0.06^{\mathrm{b}}$ & $3.82 \pm 0.04^{b}$ & $64.54 \pm 0.37^{d}$ & $21.99 \pm 0.21^{\mathrm{a}}$ & $72.58 \pm 0.28^{d}$ & $22.08 \pm 0.22^{\mathrm{a}}$ & $5.36 \pm 0.15^{\mathrm{a}}$ & $27.68 \pm 0.19^{a}$ & \\
\hline & 70 & $0.23 \pm 0.04^{\mathrm{b}}$ & $97.68 \pm 0.06^{a}$ & $2.09 \pm 0.07^{c}$ & $66.14 \pm 0.16^{\mathrm{b}}$ & $20.55 \pm 0.25^{c}$ & $74.37 \pm 0.23^{\mathrm{b}}$ & $20.63 \pm 0.37^{c}$ & $4.98 \pm 0.26^{\mathrm{a}}$ & $25.62 \pm 0.18^{c}$ & \\
\hline & 90 & $0.31 \pm 0.04^{\mathrm{a}}$ & $95.33 \pm 0.04^{\mathrm{c}}$ & $4.36 \pm 0.05^{\mathrm{a}}$ & $65.80 \pm 0.17^{\mathrm{b}}$ & $20.86 \pm 0.29^{c}$ & $74.01 \pm 0.21^{\mathrm{b}}$ & $20.94 \pm 0.26^{c}$ & $5.05 \pm 0.38^{\mathrm{a}}$ & $25.71 \pm 0.24^{c}$ & 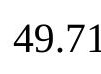 \\
\hline & 110 & $0.24 \pm 0.03^{\mathrm{b}}$ & $95.91 \pm 0.03^{b}$ & $3.85 \pm 0.06^{b}$ & $65.17 \pm 0.33^{c}$ & $21.42 \pm 0.18^{\mathrm{b}}$ & $73.29 \pm 0.29^{c}$ & $21.49 \pm 0.21^{\mathrm{b}}$ & $5.22 \pm 0.18^{\mathrm{a}}$ & $26.36 \pm 0.12^{\mathrm{b}}$ & 45. \\
\hline
\end{tabular}

As= agitation speed, Ol=Olein, St= Stearin, SAFA= Saturated fatty acid, MUFA= monounsaturated fatty acid, PUFA= polyunsaturated fatty acid. Each value in table represent the mean \pm standard deviation of sample analysis from triplicate analysis. Mean within each column with different superscripts are significantly $(\mathrm{P}<0.05)$ different. 


\section{Table 5(on next page)}

Slip melting point of PDAG olein and stearin . 


\begin{tabular}{lccccc}
\hline & \multicolumn{5}{c}{ Cooling rate $\left({ }^{\circ} \mathbf{C} / \mathbf{m i n}\right)$} \\
Olein & $\mathbf{0 . 0 5}$ & $\mathbf{0 . 5 0}$ & $\mathbf{1 . 0 0}$ & $\mathbf{1 . 5 0}$ & $\mathbf{2 . 0 0}$ \\
\cline { 2 - 6 } Stearin & $30.0 \pm 0.50^{\mathrm{c}}$ & $30.0 \pm 0.50^{\mathrm{c}}$ & $30.0 \pm 0.20^{\mathrm{c}}$ & $31.8 \pm 0.20^{\mathrm{b}}$ & $37.8 \pm 0.20^{\mathrm{a}}$ \\
& $62.5 \pm 0.20^{\mathrm{a}}$ & $61.6 \pm 0.30^{\mathrm{b}}$ & $61.8 \pm 0.30^{\mathrm{b}}$ & $62.0 \pm 0.30^{\mathrm{b}}$ & $62.0 \pm 0.10^{\mathrm{b}}$ \\
\hline \multicolumn{5}{c}{ Crystallization temperature $\left({ }^{\circ} \mathbf{C}\right)$} \\
Olein & $\mathbf{3 0}$ & $\mathbf{3 5}$ & $\mathbf{4 0}$ & $\mathbf{4 5}$ & $\mathbf{5 0}$ \\
\cline { 2 - 6 } Stearin & $28.6 \pm 0.20^{\mathrm{e}}$ & $28.0 \pm 0.20^{\mathrm{d}}$ & $32.0 \pm 0.20^{\mathrm{c}}$ & $34.4 \pm 0.20^{\mathrm{b}}$ & $44.0 \pm 0.30^{\mathrm{a}}$ \\
& $62.0 \pm 0.20^{\mathrm{b}}$ & $62.0 \pm 0.40^{\mathrm{b}}$ & $62.4 \pm 0.20^{\mathrm{ab}}$ & $62.6 \pm 0.26^{\mathrm{a}}$ & $62.6 \pm 0.20^{\mathrm{a}}$ \\
\hline \multirow{5}{*}{ Agitation speed (rpm) } \\
Olein & $\mathbf{3 0}$ & $\mathbf{5 0}$ & $\mathbf{7 0}$ & $\mathbf{9 0}$ & $\mathbf{1 1 0}$ \\
\cline { 2 - 6 } Stearin & $26.5 \pm 0.26^{\mathrm{c}}$ & $27.0 \pm 0.20^{\mathrm{b}}$ & $27.4 \pm 0.20^{\mathrm{ab}}$ & $27.1 \pm 0.26^{\mathrm{ab}}$ & $27.5 \pm 0.20^{\mathrm{a}}$ \\
& $61.4 \pm 0.17^{\mathrm{a}}$ & $60.2 \pm 0.20^{\mathrm{b}}$ & $60.2 \pm 0.36^{\mathrm{b}}$ & $60.2 \pm 0.20^{\mathrm{b}}$ & $60.2 \pm 0.10^{\mathrm{b}}$ \\
\hline
\end{tabular}




\section{Figure 1}

Solid fat content of PDAG fat, stearin and olein fractionated at different cooling rate.

St, stearin; Ol, olein; cooling rates in ${ }^{\circ} \mathrm{C} / \mathrm{min}, 0.05,0.50,1.00,1.50$ and 2.00.

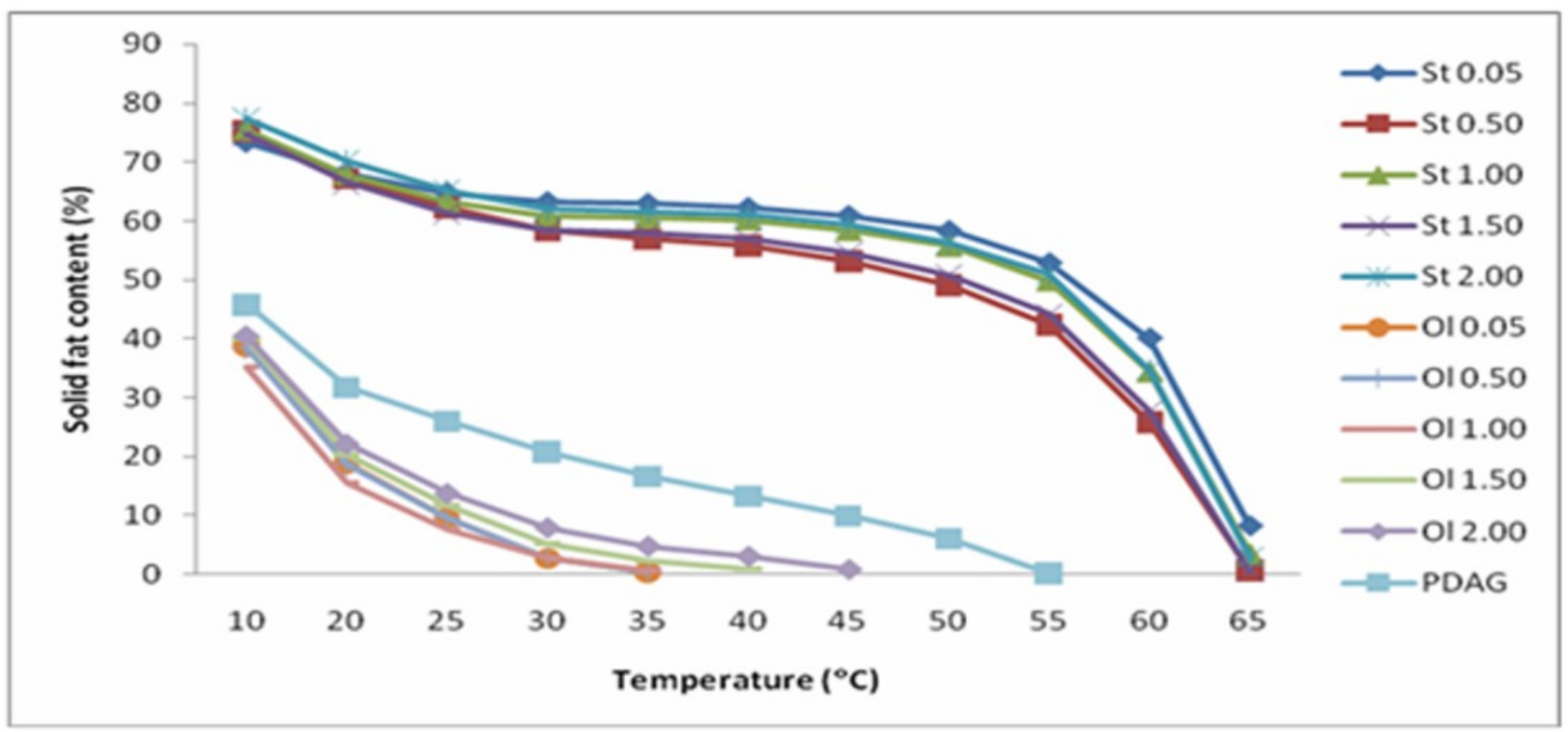




\section{Figure 2}

Solid fat content of palm-based DAG fat, stearin and olein fractionated at different crystallization temperature.

St, stearin; Ol, olein; crystallization temperature in ${ }^{\circ} \mathrm{C}, 30,35,40,45$ and 50.

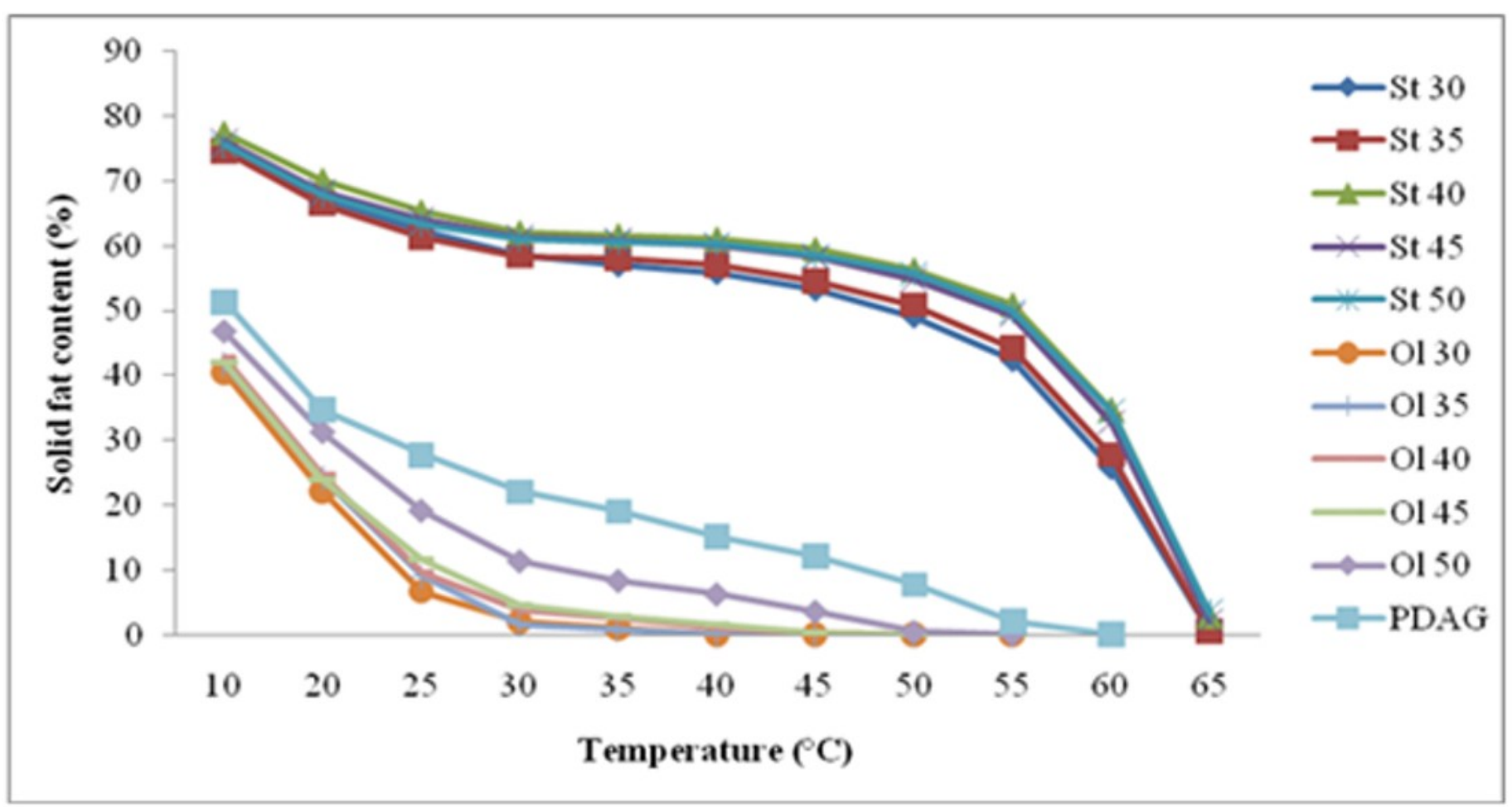




\section{Figure 3}

Solid fat content of palm-based DAG fat, stearin and olein fractionated at different agitation speed.

St, stearin; Ol, olein; agitation speed in rpm, 30, 50, 70, 90 and 110.

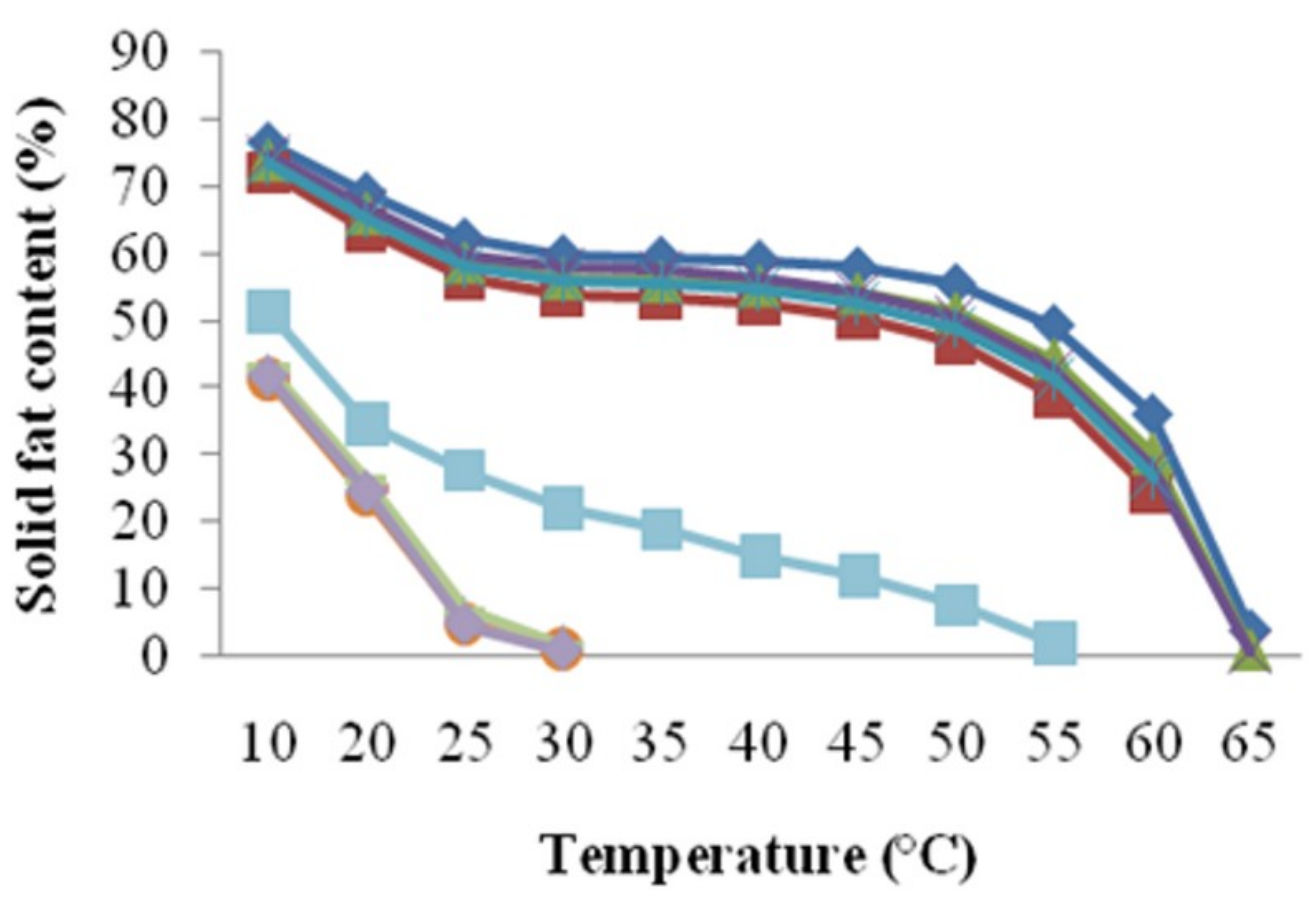

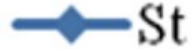
30 - - St 50 $-\mathrm{St}$ 70 $\leadsto \mathrm{St}$ 90 - St 110 $\mathrm{Ol}$ 30 


\section{Figure 4}

DSC crystallization curve of olein fraction obtained by fractionation at different cooling rates.

1; PDAG fat, Olein fractionated at $2 ; 0.05^{\circ} \mathrm{C} / \mathrm{min}, 3 ; 0.50^{\circ} \mathrm{C} / \mathrm{min}, 4 ; 1.00^{\circ} \mathrm{C} / \mathrm{min}, 5 ; 1.50^{\circ} \mathrm{C} / \mathrm{min}$ and $6 ; 2.00^{\circ} \mathrm{C} / \mathrm{min}$.

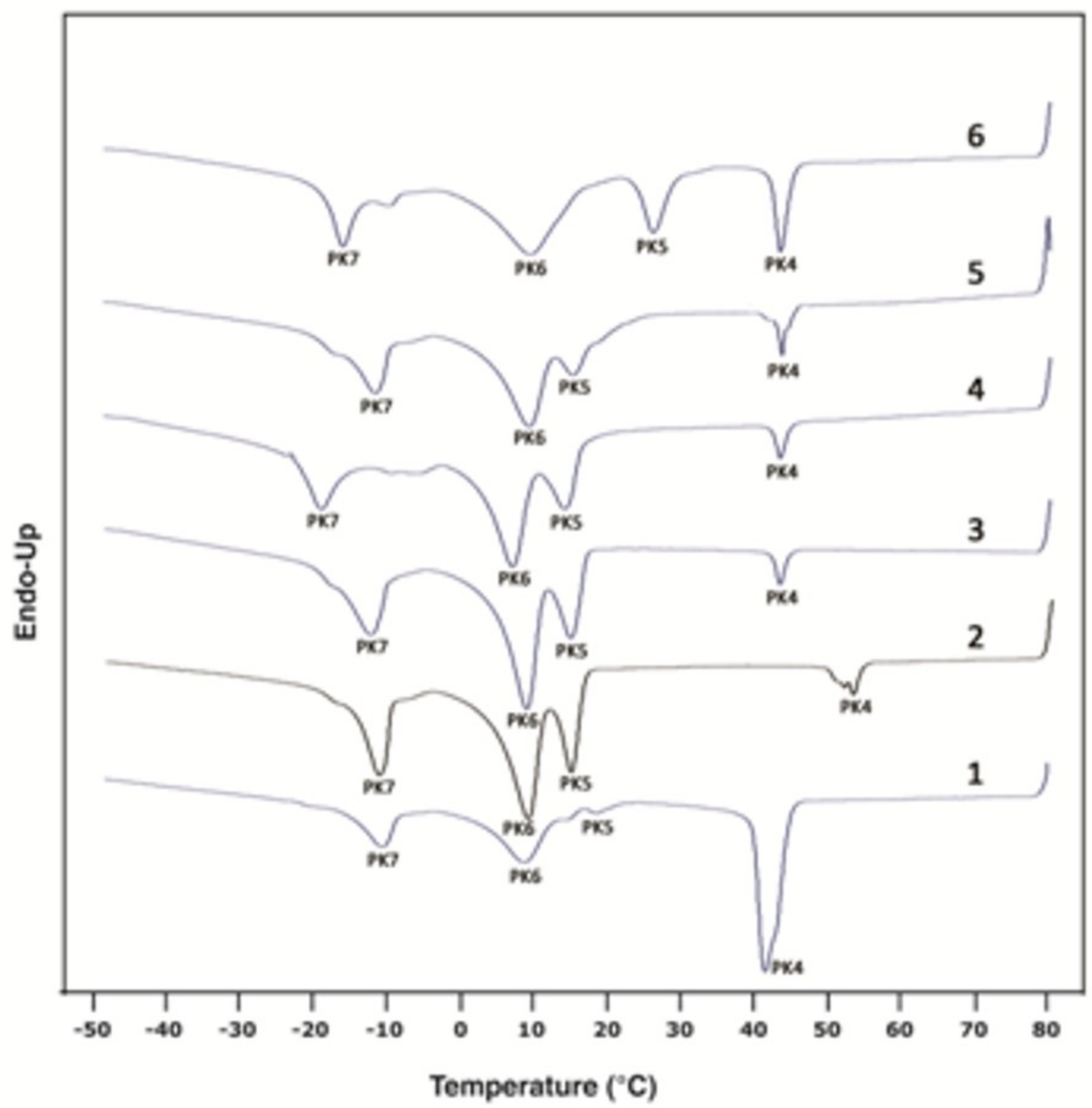




\section{Figure 5}

DSC crystallization curves of stearin fractions obtained by fractionation at different cooling rates.

1; PDAG fat, Olein fractionated at $2 ; 0.05^{\circ} \mathrm{C} / \mathrm{min}, 3 ; 0.50^{\circ} \mathrm{C} / \mathrm{min}, 4 ; 1.00^{\circ} \mathrm{C} / \mathrm{min}, 5 ; 1.50^{\circ} \mathrm{C} / \mathrm{min}$ and $6 ; 2.00^{\circ} \mathrm{C} / \mathrm{min}$.

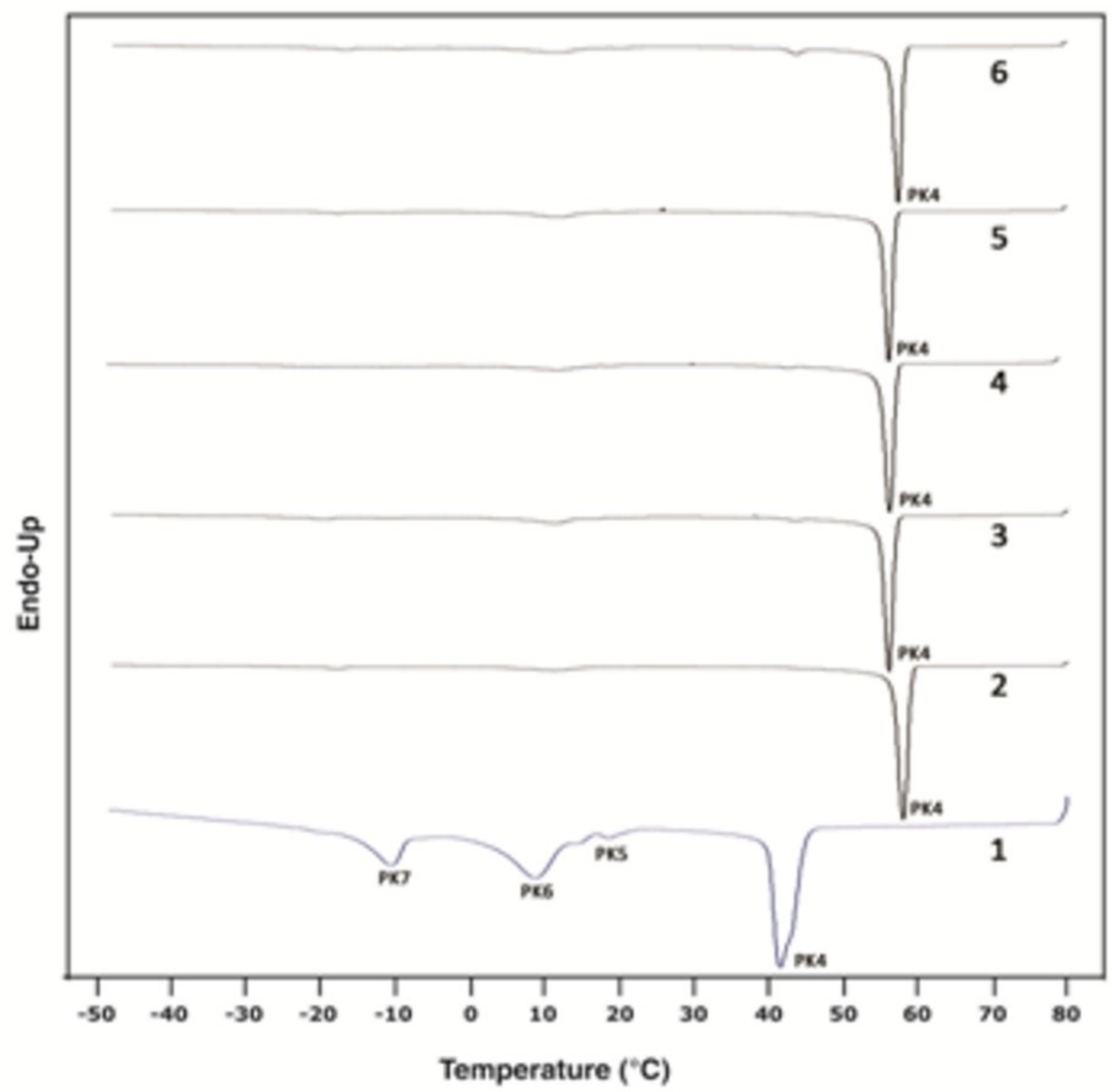




\section{Figure 6}

DSC melting curves for olein fractions obtained by fractionation at different cooling rates.

1; PDAG fat, Olein fractionated at $2 ; 0.05^{\circ} \mathrm{C} / \mathrm{min}, 3 ; 0.50^{\circ} \mathrm{C} / \mathrm{min}, 4 ; 1.00^{\circ} \mathrm{C} / \mathrm{min}, 5 ; 1.50^{\circ} \mathrm{C} / \mathrm{min}$ and $6 ; 2.00^{\circ} \mathrm{C} / \mathrm{min}$.

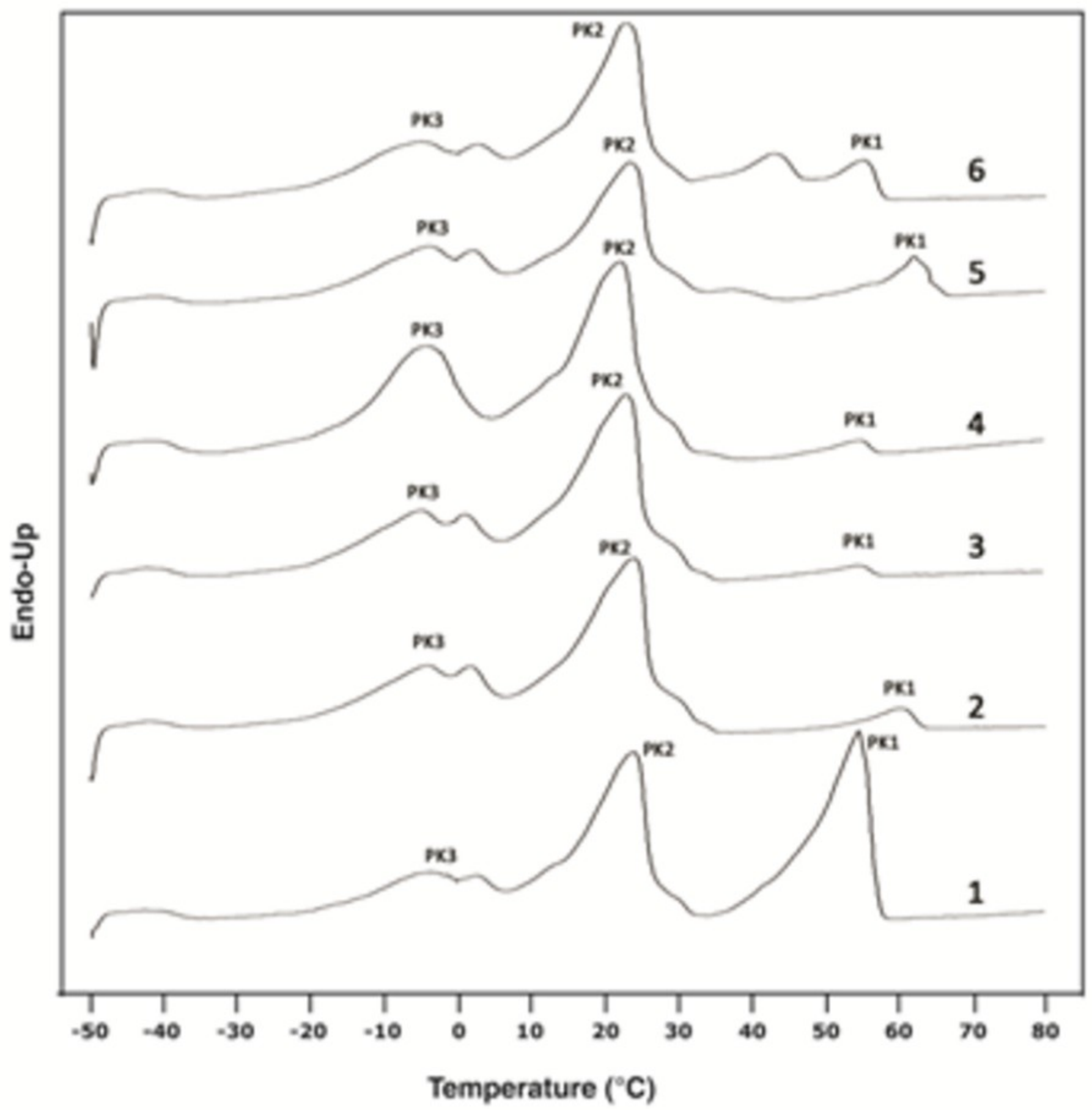




\section{Figure 7}

DSC melting curves of stearin fractions obtained by fractionation at different cooling rates.

1; PDAG fat, Olein fractionated at $2 ; 0.05^{\circ} \mathrm{C} / \mathrm{min}, 3 ; 0.50^{\circ} \mathrm{C} / \mathrm{min}, 4 ; 1.00^{\circ} \mathrm{C} / \mathrm{min}, 5 ; 1.50^{\circ} \mathrm{C} / \mathrm{min}$ and $6 ; 2.00^{\circ} \mathrm{C} / \mathrm{min}$.

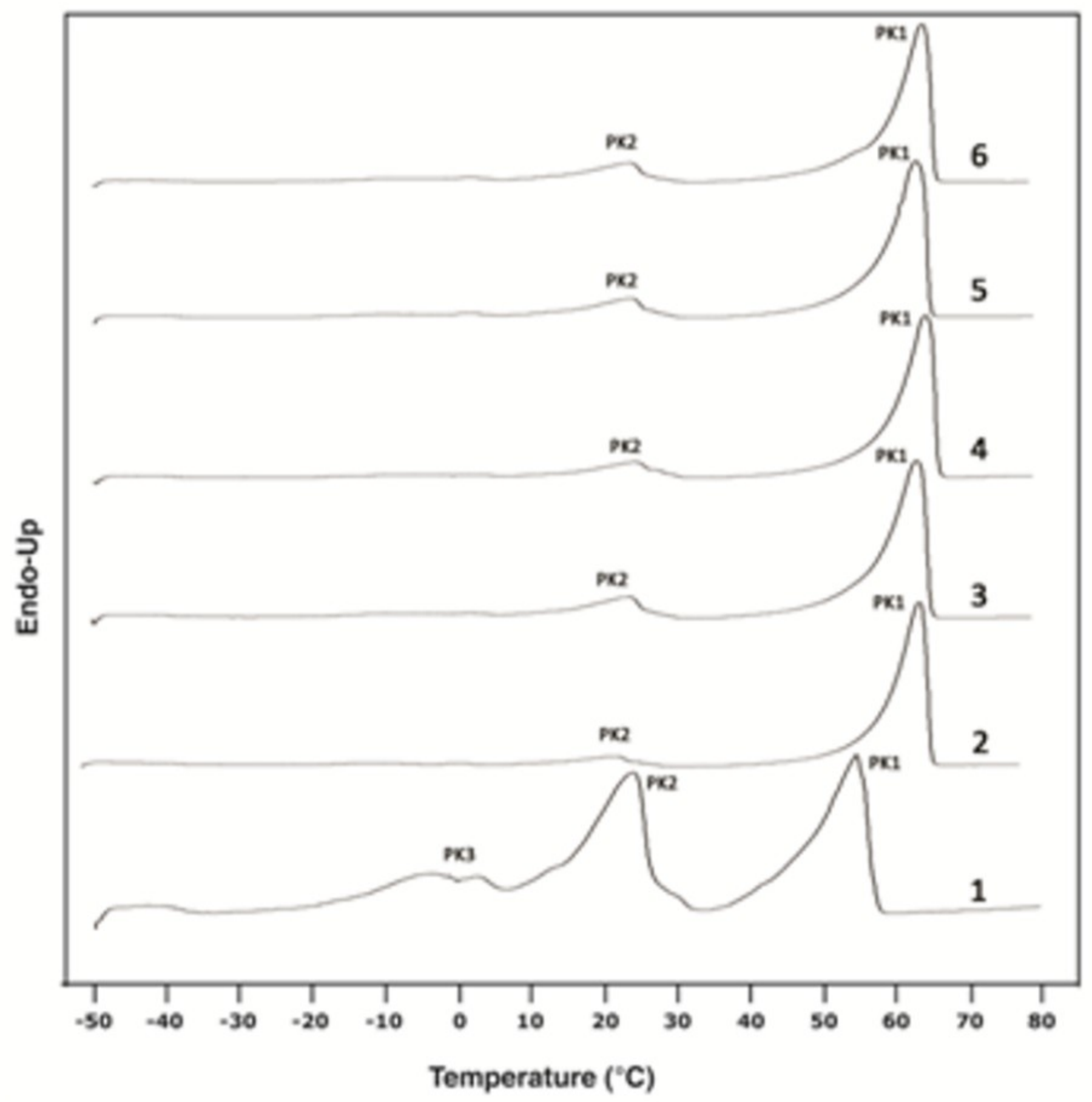




\section{Figure 8}

DSC crystallization curves of olein fractions obtained by fractionation at different crystallisation temperature.

1; PDAG fat, Olein/stearin fractionated at 2; $30^{\circ} \mathrm{C}, 3 ; 35^{\circ} \mathrm{C}, 4 ; 40^{\circ} \mathrm{C}, 5 ; 45^{\circ} \mathrm{C}$ and $6 ; 50^{\circ} \mathrm{C}$.

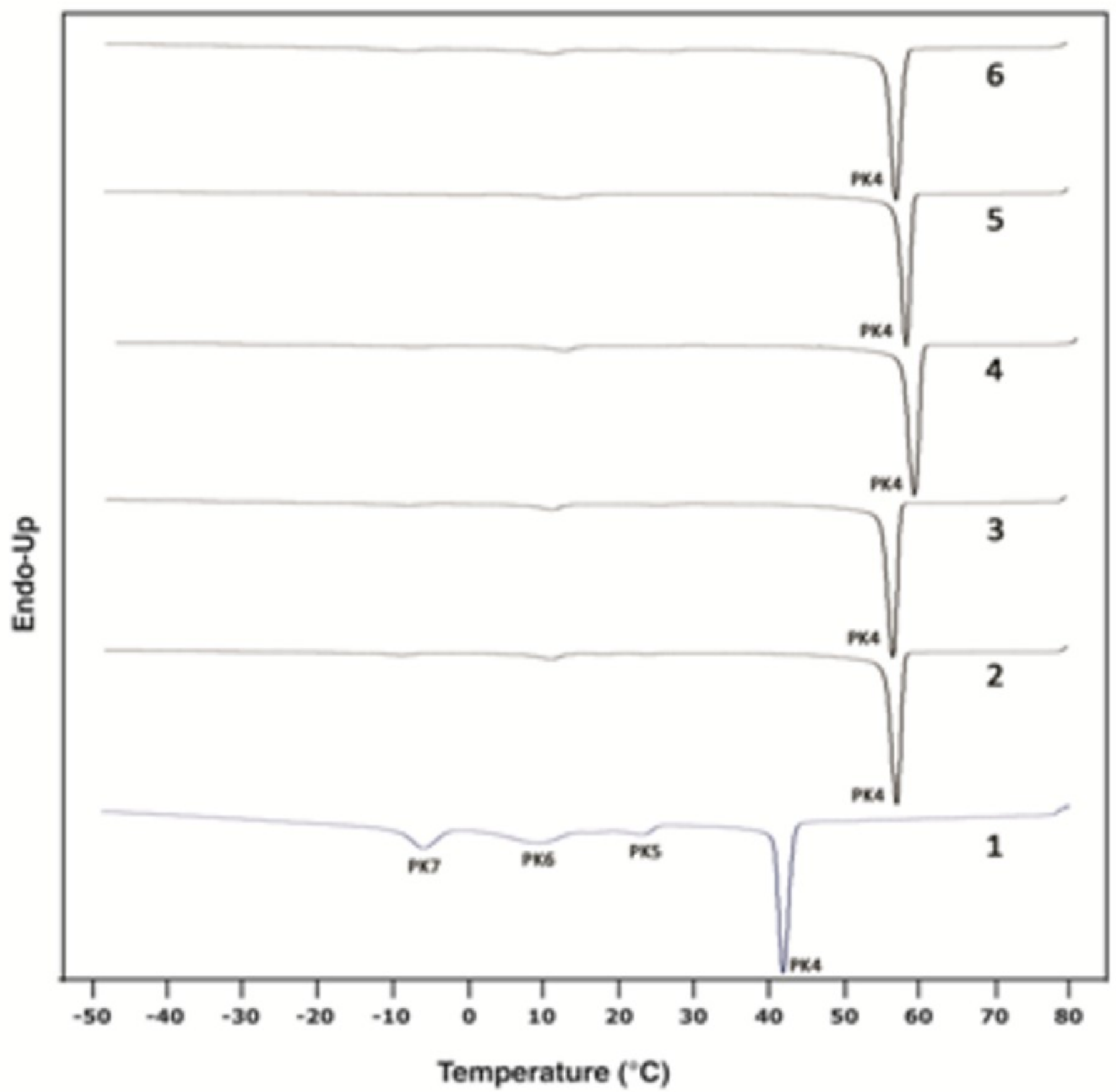




\section{Figure 9}

DSC crystallization curves of stearin fractions obtained by fractionation at different crystallisation temperature.

1; PDAG fat, Olein/stearin fractionated at 2; $30^{\circ} \mathrm{C}, 3 ; 35^{\circ} \mathrm{C}, 4 ; 40^{\circ} \mathrm{C}, 5 ; 45^{\circ} \mathrm{C}$ and $6 ; 50^{\circ} \mathrm{C}$.

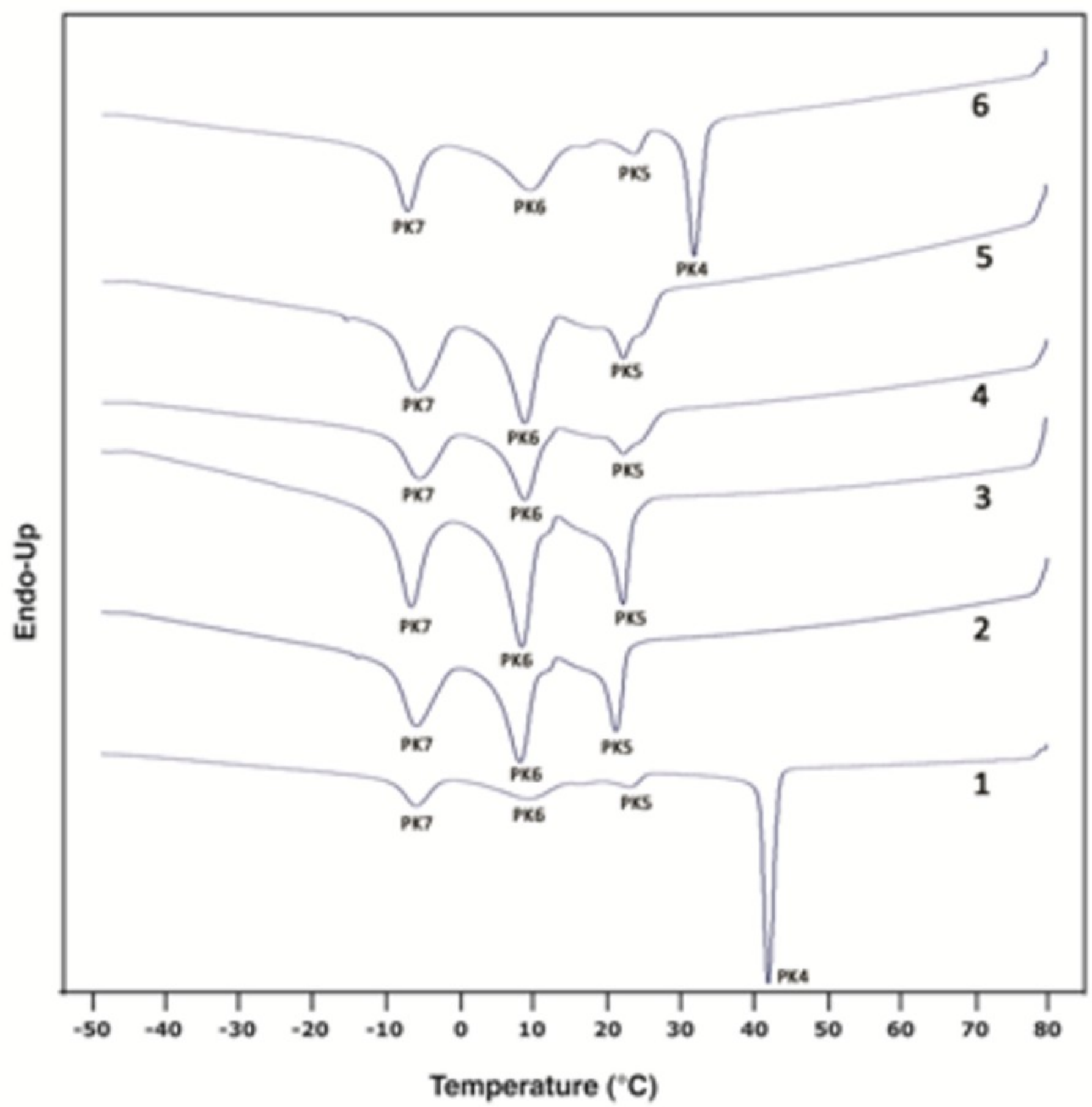




\section{Figure 10}

DSC melting curves of olein fractions obtained by fractionation at different crystallisation temperature.

1; PDAG fat, Olein/stearin fractionated at 2; $30^{\circ} \mathrm{C}, 3 ; 35^{\circ} \mathrm{C}, 4 ; 40^{\circ} \mathrm{C}, 5 ; 45^{\circ} \mathrm{C}$ and $6 ; 50^{\circ} \mathrm{C}$.

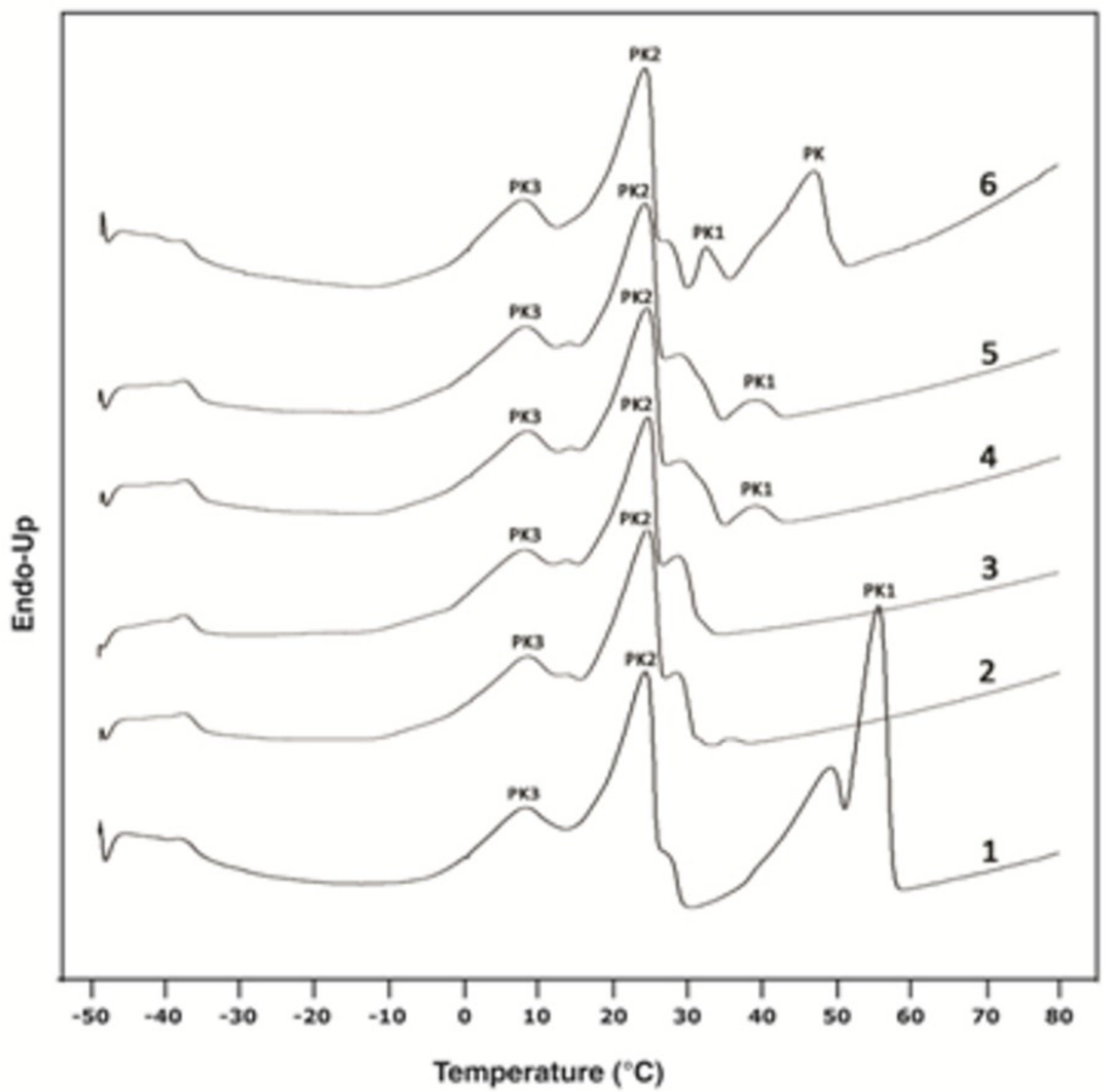




\section{Figure 11}

DSC melting curves of stearin fractions obtained by fractionation at different crystallisation temperature.

1; PDAG fat, Olein/stearin fractionated at 2; $30^{\circ} \mathrm{C}, 3 ; 35^{\circ} \mathrm{C}, 4 ; 40^{\circ} \mathrm{C}, 5 ; 45^{\circ} \mathrm{C}$ and $6 ; 50^{\circ} \mathrm{C}$.

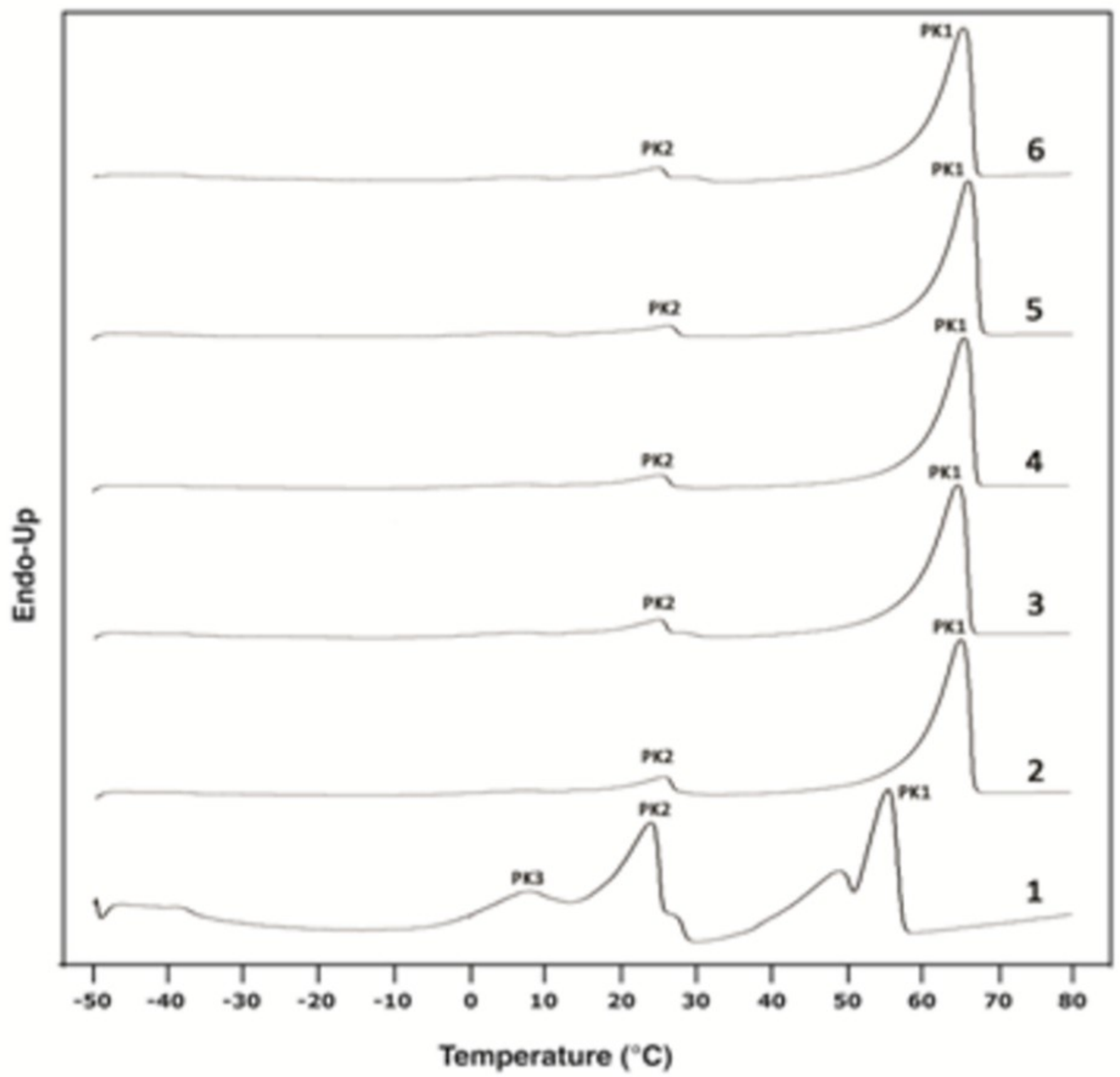




\section{Figure 12}

DSC crystallization curves of olein fractions obtained by fractionation at different agitation speed.

1; PDAG fat, Olein/stearin fractionated at 2; 30 rpm, 3; 50 rpm, 4; 70 rpm, 5; 90 rpm and 6; $110 \mathrm{rpm}$.

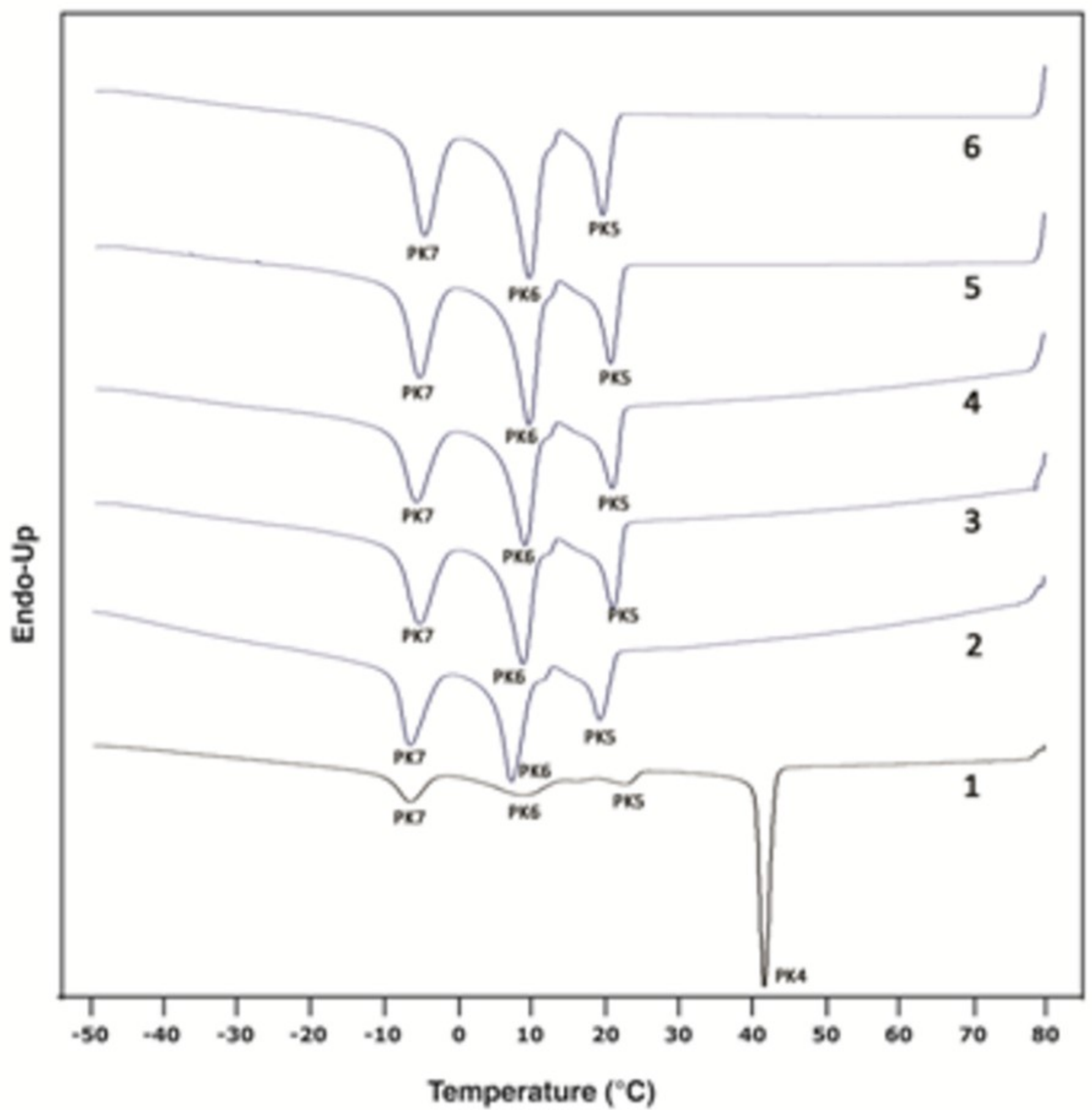




\section{Figure 13}

DSC crystallization curves of stearin fractions obtained by fractionation at different agitation speed.

1; PDAG fat, Olein/stearin fractionated at 2; 30 rpm, 3; 50 rpm, 4; 70 rpm, 5; 90 rpm and 6; $110 \mathrm{rpm}$.

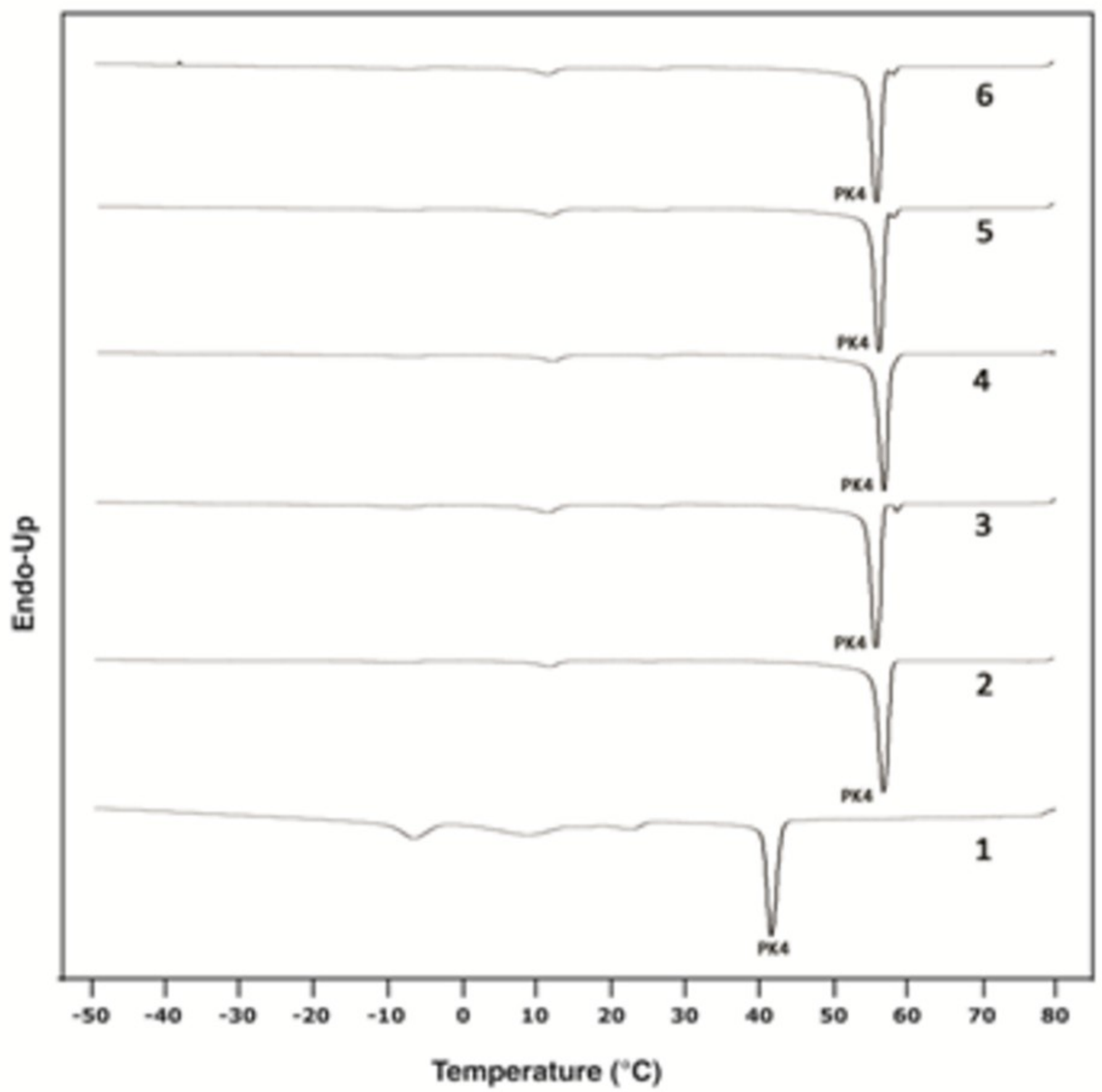




\section{Figure 14}

DSC melting curves of olein fraction obtained by fractionation at different agitation speed.

1; PDAG fat, Olein/stearin fractionated at 2; 30 rpm, 3; 50 rpm, 4; 70 rpm, 5; 90 rpm and 6; $110 \mathrm{rpm}$.

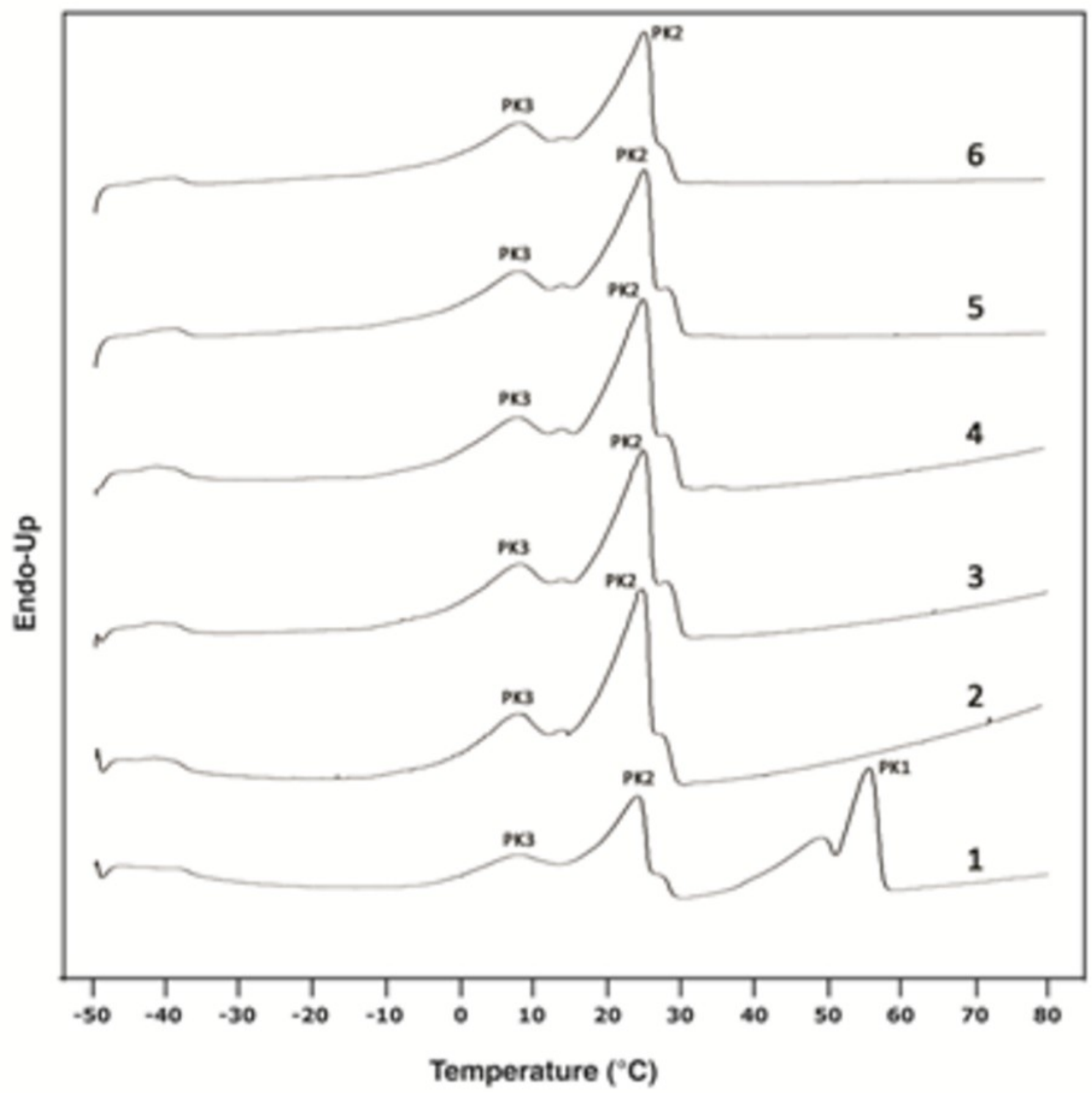




\section{Figure 15}

DSC melting curves for stearin fractions obtained by fractionation at different agitation speed.

1; PDAG fat, Olein/stearin fractionated at 2; 30 rpm, 3; 50 rpm, 4; 70 rpm, 5; 90 rpm and 6; $110 \mathrm{rpm}$.

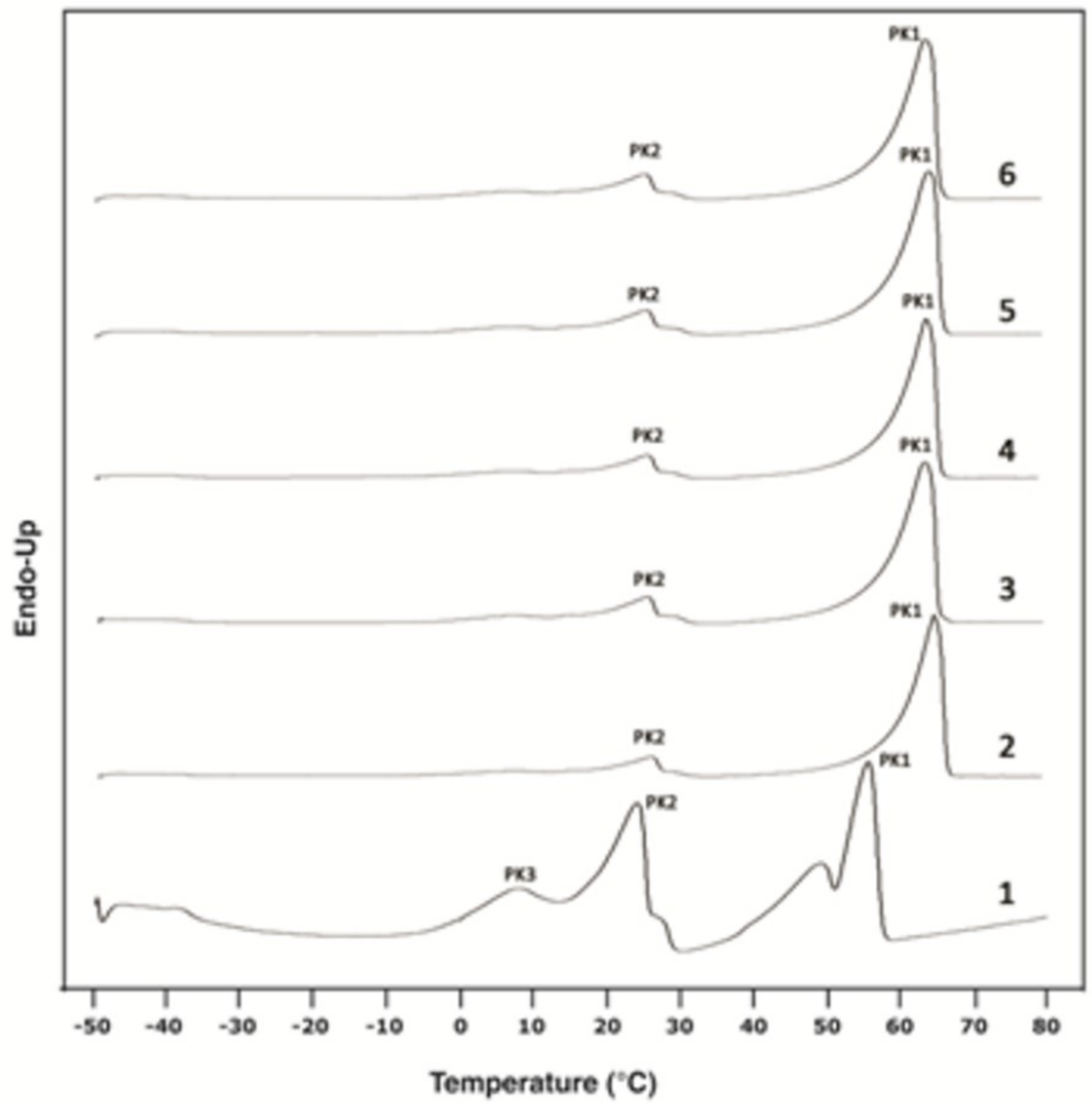

